\title{
Estimating the near-surface permafrost-carbon feedback on global warming
}

\author{
T. Schneider von Deimling ${ }^{1}$, M. Meinshausen ${ }^{1,2}$, A. Levermann ${ }^{1,5}$, V. Huber ${ }^{1}$, K. Frieler ${ }^{1}$, D. M. Lawrence ${ }^{3}$, and \\ V. Brovkin 4,1 \\ ${ }^{1}$ Potsdam Institute for Climate Impact Research, Potsdam, Germany \\ ${ }^{2}$ School of Earth Sciences, The University of Melbourne, Victoria, Australia \\ ${ }^{3}$ Climate and Global Dynamics Division, National Center for Atmospheric Research, Boulder, Colorado, USA \\ ${ }^{4}$ Max Planck Institute for Meteorology, Hamburg, Germany \\ ${ }^{5}$ Potsdam University, Potsdam, Germany
}

Correspondence to: T. Schneider von Deimling (schneider@ pik-potsdam.de)

Received: 1 March 2011 - Published in Biogeosciences Discuss.: 12 May 2011

Revised: 20 November 2011 - Accepted: 6 January 2012 - Published: 3 February 2012

\begin{abstract}
Thawing of permafrost and the associated release of carbon constitutes a positive feedback in the climate system, elevating the effect of anthropogenic GHG emissions on global-mean temperatures. Multiple factors have hindered the quantification of this feedback, which was not included in climate carbon-cycle models which participated in recent model intercomparisons (such as the Coupled Carbon Cycle Climate Model Intercomparison Project $-\mathrm{C}^{4} \mathrm{MIP}$ ) . There are considerable uncertainties in the rate and extent of permafrost thaw, the hydrological and vegetation response to permafrost thaw, the decomposition timescales of freshly thawed organic material, the proportion of soil carbon that might be emitted as carbon dioxide via aerobic decomposition or as methane via anaerobic decomposition, and in the magnitude of the high latitude amplification of global warming that will drive permafrost degradation. Additionally, there are extensive and poorly characterized regional heterogeneities in soil properties, carbon content, and hydrology. Here, we couple a new permafrost module to a reduced complexity carbon-cycle climate model, which allows us to perform a large ensemble of simulations. The ensemble is designed to span the uncertainties listed above and thereby the results provide an estimate of the potential strength of the feedback from newly thawed permafrost carbon. For the high $\mathrm{CO}_{2}$ concentration scenario (RCP8.5), 33-114 GtC (giga tons of Carbon) are released by 2100 (68\% uncertainty range). This leads to an additional warming of $0.04-0.23^{\circ} \mathrm{C}$. Though projected 21 st century permafrost carbon emissions
\end{abstract}

are relatively modest, ongoing permafrost thaw and slow but steady soil carbon decomposition means that, by 2300, about half of the potentially vulnerable permafrost carbon stock in the upper $3 \mathrm{~m}$ of soil layer $(600-1000 \mathrm{GtC})$ could be released as $\mathrm{CO}_{2}$, with an extra $1-4 \%$ being released as methane. Our results also suggest that mitigation action in line with the lower scenario RCP3-PD could contain Arctic temperature increase sufficiently that thawing of the permafrost area is limited to $9-23 \%$ and the permafrost-carbon induced temperature increase does not exceed $0.04-0.16^{\circ} \mathrm{C}$ by 2300 .

\section{Introduction}

The climate response to anthropogenic greenhouse gas emissions is markedly influenced by internal Earth system feedbacks. Carbon cycle feedbacks (Cramer et al., 2001; Friedlingstein et al., 2006; Sitch et al., 2008) are among the most prominent examples of such internal feedbacks, where an initial increase in temperature triggers a reaction from land biomass and soils that leads to increased carbon emissions, which in turn amplifies the warming. The strength of this carbon cycle - climate feedback $\left(\gamma_{\mathrm{L}}\right)$ is generally measured as cumulative carbon release (or reduced uptake) per degree of warming. This average land carbon sensitivity $\gamma_{\mathrm{L}}$ is $+79 \mathrm{GtC}^{\circ} \mathrm{C}^{-1}$ up to 2100 across the $\mathrm{C}^{4} \mathrm{MIP}$ generation of carbon cycle models (Friedlingstein et al., 2006) under the high A2 forcing scenario (Special Report on Emission 
Scenarios-SRES). Additional release of carbon from newly thawed permafrost, referred to as "permafrost-carbon feedback" in the following, would add to this land carbon feedback. At present, the release of additional carbon to the atmosphere as carbon dioxide or methane due to the thawing of permafrost and the subsequent decomposition of the soil organic carbon is not typically represented in carbon cycle models. For example, none of the carbon cycle models participating in $\mathrm{C}^{4} \mathrm{MIP}$ (Friedlingstein et al., 2006) included this feedback.

The carbon feedback from high latitude regions and its importance for the future climate is rather unconstrained, with uncertainties existing in the overall availability and quality of carbon stored in frozen soils, permafrost thawing rates, organic matter decomposition rates and, importantly, the relative proportion of anaerobic decomposition (resulting in $\mathrm{CO}_{2}$ and $\mathrm{CH}_{4}$ emissions) versus aerobic decomposition (resulting in $\mathrm{CO}_{2}$ emissions only). A broader discussion of uncertainties relevant to the permafrost carbon feedback can be found in (Schuur et al., 2008; McGuire et al., 2009; Davidson and Janssens, 2006; O'Connor et al., 2010; Grosse et al., 2011).

However, the permafrost feedback uncertainties are basically "one-sided", i.e. the inclusion of the permafrost-carbon feedback will most likely increase future climate impacts (see discussion of potential negative permafrost feedbacks in Sect. 4). Although some feedbacks that dampen global warming might be triggered, such as vegetation growth induced by permafrost thaw and the release of plant-available nutrients, there is little reason to believe that the net effect of large-scale permafrost thaw would lower future temperature rise (McGuire et al., 2006).

The potential magnitude of the permafrost-carbon feedback is substantial given that approximately thousand Gigatons (10^9 tons) of organic carbon is stored in the upper $3 \mathrm{~m}$ of permafrost soil alone (Schuur et al., 2008). The total carbon pool in permafrost areas is as high as $1672 \mathrm{GtC}$, if deeper Yedoma and Deltaic carbon deposits are included, $88 \%$ of which reside in perennially frozen ground, as estimated by a recent and updated meta-data analysis (Tarnocai et al., 2009). These numbers can be put into perspective with fossil fuel emissions from the recent Representative Concentration Pathways (RCPs), which succeed previous SRES emission scenarios. In these new scenarios, GHG concentrations are extended beyond 2100 until year 2300. Overall, the new scenario RCP4.5 is comparable to the previously lowest scenario SRES B1 and RCP8.5 is comparable to the previously highest scenario SRES A1FI ${ }^{1}$.

The accumulated anthropogenic fossil fuel $\mathrm{CO}_{2}$ emissions for the medium-low RCP4.5 scenario amount $1000 \mathrm{GtC}$ over years 2000 to 2300 (cf. figure $3 \mathrm{~b}$ in Meinshausen et al., 2011b) - comparable in magnitude to the current atmospheric $\mathrm{CO}_{2}$ content of about $830 \mathrm{GtC}$. Allen et al. (2009) es-

\footnotetext{
${ }^{1}$ see Fig. $\mathrm{S} 1$ in the Supplement for scenario specific $\mathrm{CO}_{2}$ concentrations (SRES and RCPs).
}

timated a most likely $\mathrm{CO}_{2}$-induced warming of $2{ }^{\circ} \mathrm{C}$ for total (historical and future) anthropogenic emissions of $1000 \mathrm{Pg}$.

The purpose of this study is to provide a first probabilistic estimate of the importance of the permafrost-carbon feedback for the global temperature rise. We investigate this question for the set of all four Representative Concentration Pathways (RCPs) (van Vuuren et al., 2011; Moss et al., 2010). For climatic consequences without permafrost feedback refer to Schewe et al. (2011).

\section{Modeling approach}

\subsection{General approach and terminology}

This section provides an overview of the simulation setup, of our simplified permafrost module, and of the climate model used to run the different emission scenarios. Our study intends to provide a snapshot of the current scientific understanding by combining modeling results from the permafrost soil community with evidence from observational and simulation studies of soil microbial processes. Integrating a permafrost module into a reduced complexity carbon cycle climate model enables us to provide a first probabilistic estimate of the permafrost-carbon effects on global mean temperature projections. We chose this computationally efficient approach to investigate parameter uncertainties in a probabilistic framework over the century long timescales involved, here until 2300. Thus, our approach intends to synthesize and supplement, not to bypass, the highly resolved and processbased permafrost modeling endeavors.

In this study we define the "permafrost-carbon feedback" as the contribution of near-surface permafrost carbon (upper $3 \mathrm{~m}$ ) which is presently stored in perennially frozen ground. The full permafrost-carbon feedback is also affected by climate driven changes in background emissions in permafrost regions. These emissions result from changes in respiration of Arctic soil carbon, which is stored in the active layer under present day climate. Another contribution to background emissions results from vegetation induced carbon fluxes in permafrost regions - through higher $\mathrm{CO}_{2}$ fertilization and increased $\mathrm{CO}_{2}$ uptake from vegetation growth. In our analysis we account for higher $\mathrm{CO}_{2}$ sequestration through fertilization given the calibration of MAGICC6 to the $\mathrm{C}^{4} \mathrm{MIP}$ carbon cycle models. As only a few $\mathrm{C}^{4} \mathrm{MIP}$ models included dynamic vegetation modules, our emulations do likewise not fully capture modified carbon fluxes resulting from vegetation-driven changes in permafrost regions. We also do not account for changes in soil respiration from surface layers above our considered permafrost pool (see Sect. 2.3). Increased respiration from these surface soil layers and increased carbon uptake through vegetation growth cancel out to a certain extent (they might cancel out almost completely, see Koven et al., 2011). A further compensation comes from changes in surface albedo (see discussion in Sect. 4). 
So we expect that our inferred carbon fluxes which define the "permafrost-carbon feedback" are a good approximation to the overall strength of the full near-surface permafrostcarbon feedback.

\subsection{Climate carbon-cycle model and simulation setup}

For investigating the climatic effect of future carbon release from thawing permafrost soils we apply MAGICC6, the latest version of a reduced complexity carbon cycle climate model (see e.g. Wigley and Raper, 2002), described in Meinshausen et al. (2011a). MAGICC6's carbon cycle can closely emulate 10 high-complexity carbon cycle models that took part in $C^{4}$ MIP (Friedlingstein et al., 2006) with respect to their main carbon pools, fluxes and atmospheric $\mathrm{CO}_{2}$ concentrations in no-feedback and with-feedback carbon cycle experiments. MAGICC6 also includes gas-cycle parameterizations for methane, including temperature and OH-dependent lifetimes (Ehhalt et al., 2001).

Emissions from the thawing of permafrost soils, however, have not been taken into account neither in $\mathrm{C}^{4} \mathrm{MIP}$ models nor in MAGICC6. Adding the carbon dioxide and methane emissions from the permafrost module (described in the next section) to MAGICC6's gas cycles, and feeding back the respective temperatures at each time step to the permafrost and carbon cycle module allows an integrated and internally consistent analysis.

Here, we use a probabilistic version of MAGICC6, which was calibrated to reflect historical observations of surface air temperatures and ocean heat uptake, as described in Meinshausen et al. (2011a). We combine 2400 equally likely drawings from the 82-dimensional joint probability distribution for this historically constrained climate model with random drawings of 9 sets of carbon cycle model parameters, as well as random drawings from uniform and independent distributions of 22 parameters in our permafrost module (see Table 1). Each of the 9 carbon cycle parameter sets contains 17 individual parameters to emulate one of the $\mathrm{C}^{4} \mathrm{MIP}$ models, as described in (Meinshausen et al., 2011a). We did not include any IPSL CM2C emulations, as the air-to-ocean carbon flux beyond 2100 (i.e. beyond the time horizon of $\mathrm{C}^{4} \mathrm{MIP}$ and hence the MAGICC calibration period) is emulated substantially stronger than shown for the IPSL previously (Orr, 2002).

We do not prescribe the RCP8.5 GHGs concentrations, but calculate these dynamically using RCP 8.5 emissions, so that added permafrost emissions will have an effect on $\mathrm{CO}_{2}$ and $\mathrm{CH}_{4}$ concentrations and simulated temperatures. Thus, we start our analysis from the harmonized set of greenhouse gas, aerosol and tropospheric ozone precursor RCP emissions, as they were used for creating the RCP GHG concentrations.

In addition to our large ensemble simulations, we perform a single illustrative run with default parameter settings for our permafrost module in order to illustrate the dynamics over century long timescales. For this, we use MAGICC6 settings that are identical to those used for producing the RCP concentration scenarios (Meinshausen et al., 2011b). Specifically, MAGICC6's carbon cycle is calibrated towards the $\mathrm{C}^{4} \mathrm{MIP}$ Bern 2.5CC carbon cycle model, and the climate response parameters reflect a median projection across the models of the third phase of the Coupled Model Intercomparison Project (CMIP3). For the permafrost module, we assume default settings as listed in Table 1, ("Default").

\subsection{Permafrost module}

Here, we provide a conceptual overview of our simplified permafrost module and its main parameter assumptions (see Table 1), with the Appendix providing a detailed mathematical description. Our permafrost module compartmentalizes the organic carbon of permafrost regions into bins with a similar warming threshold, above which permafrost will start thawing. In our simplified framework, neglecting topography and local climate as well as soil conditions, we call these bins "zonal bands", given that - generally speaking - the southernmost permafrost regions of the Northern Hemisphere are likely to start thawing first, and the northernmost regions last. This spatio-temporal characteristic of permafrost thaw is also seen in process-based modeling studies of permafrost degradation (Zhuang et al., 2006).

We assume the frozen carbon content that is potentially vulnerable to decomposition in the upper $3 \mathrm{~m}$ in permafrost soils to be between 600 and $1000 \mathrm{GtC}$. As past decomposition has left carbon of low quality in the soils before incorporation into permafrost (Schuur et al., 2008), we consider only the fraction of soil carbon which decomposes on a decadal to centennial timescale (intermediate pool) while we do not account for carbon emissions from the slow pool which eventually gets decomposed on millennial timescales. Based on Koven et al. (2011) we consider $60 \%$ of the permafrost carbon available for decomposition in the intermediate pool, and account for uncertainty in this fraction by considering a large spread in the total pool size of 600 to $1000 \mathrm{GtC}$. Our assumption is somewhat lower than recent best-guess estimates of $1024 \mathrm{GtC}$ of top $3 \mathrm{~m}$ soil carbon content in the permafrost zone (Tarnocai et al., 2009; Schuur et al., 2008), as we consider only the fraction of permafrost carbon in perennially frozen ground. A small portion of the estimated $1000 \mathrm{GtC}$ carbon pool will always reside in nearsurface layers, with expected carbon densities approaching those of non-permafrost soils.

By default, we assume this potentially vulnerable permafrost carbon content to be uniformly distributed into 50 zonal bands, while for our uncertainty-based projections (see Sect. 3.2) we vary the carbon content across the latitudinal bands (see Appendix A1). We assume the "southernmost" band to start thawing at any warming above present day levels $\left(T_{\min }=1^{\circ} \mathrm{C}\right)$, and the "northernmost" band starting to thaw at an Arctic warming above pre-industrial levels of $10-15^{\circ} \mathrm{C}$ (see Fig. 1). Several studies have suggested that 
Table 1. Default and sensitivity range parameters of the permafrost module. Sensitivity ranges are sampled from a uniform distribution between the stated minimal and maximal value. When applicable, parameter ranges were inferred from or estimated based on published studies.

\begin{tabular}{|c|c|c|c|c|c|}
\hline & Description & Unit & Default & Sensitivity & References Range \\
\hline $\mathrm{N}$ & Number of zonal bands & & 50 & 50 & \\
\hline$T_{\max }$ & $\begin{array}{l}\text { Regional arctic temperature anomaly } \\
\text { threshold for "northernmost" zonal band }\end{array}$ & ${ }^{\circ} \mathrm{C}$ & 12.5 & {$\left[\begin{array}{ll}10 & 15\end{array}\right]$} & Lawrence et al. (2011) \\
\hline$T_{\min }$ & $\begin{array}{l}\text { Regional arctic temperature anomaly } \\
\text { threshold for "southernmost" zonal band }\end{array}$ & ${ }^{\circ} \mathrm{C}$ & 1.0 & 1.0 & $(*)$ \\
\hline$\beta_{\mathrm{ms}}$ & $\begin{array}{l}\text { Effective freezing or thawing rate of } \\
\text { mineral soil fraction }\end{array}$ & $\%{ }^{\circ} \mathrm{C}^{-1} \mathrm{yr}^{-1}$ & 0.1 & {$\left[\begin{array}{lll}0.05 & 0.15\end{array}\right]$} & $(* *)$ \\
\hline$\beta_{\text {peat }}$ & $\begin{array}{l}\text { Effective freezing or thawing rate of } \\
\text { peatland soil fraction }\end{array}$ & $\%{ }^{\circ} \mathrm{C}^{-1} \mathrm{yr}^{-1}$ & 0.05 & {$\left[\begin{array}{lll}0.025 & 0.075\end{array}\right]$} & $(* * *)$ \\
\hline$\alpha$ & $\begin{array}{l}\text { Amplification of global warming over } \\
\text { permafrost area rel. to global mean warming }\end{array}$ & ${ }^{\circ} \mathrm{C}^{\circ} \mathrm{C}^{-1}$ & 1.6 & {$[1.42]$} & Frieler et al. (2011) \\
\hline$\Phi$ & $\begin{array}{l}\text { Amplitude of annual temperature cycle } \\
\text { in upper soil }\end{array}$ & ${ }^{\circ} \mathrm{C}$ & 5 & [4 6] & Khvorostyanov et al. (2008c) \\
\hline$\tau_{\mathrm{ms}, \text { aer }}$ & $\begin{array}{l}\text { Turnovertime of aerobic mineral soil } \\
\text { fraction at } 10^{\circ} \mathrm{C}\end{array}$ & Yrs & 20 & {$[1040]$} & $\begin{array}{l}\text { Sitch et al. (2003); } \\
\text { Koven et al. (2011); } \\
\text { Dutta et al. (2006) }\end{array}$ \\
\hline$\lambda_{\text {an }}$ & $\begin{array}{l}Q_{10} \text { Temperature feedback norm factor } \\
\text { for anaerobic decomposition rate }\end{array}$ & ${ }^{\circ} \mathrm{C}$ & $\begin{array}{l}309 \\
\left(Q_{10}=2.3\right)\end{array}$ & $\begin{array}{l}{[256662]} \\
\left(Q_{10}=[26]\right)\end{array}$ & Walter and Heimann (2000) \\
\hline$\lambda_{\text {aer }}$ & $\begin{array}{l}Q_{10} \text { Temperature feedback norm factor } \\
\text { for aerobic decomposition rate }\end{array}$ & ${ }^{\circ} \mathrm{C}$ & $\begin{array}{l}309 \\
\left(Q_{10}=2.3\right)\end{array}$ & $\begin{array}{l}{[256513]} \\
\left(Q_{10}=[24]\right)\end{array}$ & $\begin{array}{l}\text { Lloyd and Taylor (1994); } \\
\text { Davidson and Janssens (2006); } \\
\text { Karhu et al. (2010) }\end{array}$ \\
\hline$m_{T}$ & $\begin{array}{l}\text { Temperature sensitivity of the } \\
\text { simplified soilwater parameterisation }\end{array}$ & ${ }^{\circ} \mathrm{C}^{-1}$ & 0.03 & {$[0.03 \times 0.80 .03 \times 1.2]$} & $(* * * *)$ \\
\hline$W_{\text {offset }}$ & $\begin{array}{l}\text { An offset in the simplified soilwater } \\
\text { parameterization }\end{array}$ & Mass Fraction & 0.2 & {$[0.2 \times 0.90 .2 \times 1.1]$} & $(* * * *)$ \\
\hline$W_{\min }$ & The minimal soilwater content & Mass Fraction & 0.2 & {$[0.2 \times 0.90 .2 \times 1.1]$} & $(* * * *)$ \\
\hline$R_{\text {peat } / \mathrm{ms}}$ & $\begin{array}{l}\text { Ratio of decomposition rate in } \\
\text { peatland vs. mineral soil }\end{array}$ & Fraction & 0.5 & {$\left[\begin{array}{ll}0.3 & 0.7\end{array}\right]$} & $\begin{array}{l}\text { Scanlon and Moore (2000); } \\
\text { Hobbie et al. (2000) }\end{array}$ \\
\hline$R_{\mathrm{an} / \mathrm{aer}}$ & $\begin{array}{l}\text { Ratio of anaerobic vs. aerobic } \\
\text { decomposition rate }\end{array}$ & Fraction & 0.1 & {$\left[\begin{array}{lll}1 / 40 & 1 / 7\end{array}\right]$} & $\begin{array}{l}\text { Frolking et al. (2001); } \\
\text { Scanlon and Moore (2000) }\end{array}$ \\
\hline$A_{\mathrm{ms}, \text { an }}$ & $\begin{array}{l}\text { Area fraction of mineral soil with } \\
\text { anaerobic decomposition }\end{array}$ & Fraction & 0.05 & {$\left[\begin{array}{ll}0.01 & 0.1\end{array}\right]$} & $\begin{array}{l}\text { Smith et al. (2007); } \\
\text { Walter et al. (2007b); } \\
\text { van Huissteden et al. (2011) }\end{array}$ \\
\hline$A_{\text {peat, an }}$ & $\begin{array}{l}\text { Area fraction of peatland soil with } \\
\text { anaerobic decomposition }\end{array}$ & Fraction & 0.8 & {$\left[\begin{array}{ll}0.7 & 0.9\end{array}\right]$} & Frolking et al. (2001) \\
\hline $\mathrm{C}_{0}$ & The total initial carbon pool & $\mathrm{GtC}$ & 800 & {$\left[\begin{array}{lll}600 & 1000\end{array}\right]$} & $\begin{array}{l}\text { Tarnocai et al. (2009); } \\
\text { Schuur et al. (2008) }\end{array}$ \\
\hline$R_{\mathrm{ms}}$ & Fraction of total carbon in mineral soils & Fraction & 0.8 & {$\left[\begin{array}{ll}0.7 & 0.9\end{array}\right]$} & Tarnocai et al. (2009) \\
\hline$\varphi$ & $\begin{array}{l}\text { Distribution of total carbon content towards } \\
\text { the "Southern" (1) or "Northern" Areas }(-1) \\
\text { or uniformly equal distribution }(0)\end{array}$ & & 0 & {$\left[\begin{array}{ll}-0.5 & 0.5\end{array}\right]$} & \\
\hline$\chi_{\mathrm{ms}}$ & $\begin{array}{l}\text { Fraction of methane that gets oxidized } \\
\text { in mineral soils }\end{array}$ & Fraction & 0.25 & {$\left[\begin{array}{ll}0.1 & 0.4\end{array}\right]$} & $\begin{array}{l}\text { Berrittella and van Huissteden (2009); } \\
\text { Wagner et al. (2009) }\end{array}$ \\
\hline$\chi_{\text {peat }}$ & $\begin{array}{l}\text { Fraction of methane that gets oxidized } \\
\text { in peatland soils }\end{array}$ & Fraction & 0.6 & {$\left[\begin{array}{ll}0.5 & 0.7\end{array}\right]$} & Kip et al. (2011) \\
\hline
\end{tabular}

* Tuned such that permafrost starts thawing for temperatures above present day climate.

** Effective thawing rates were tuned to yield permafrost thaw consistent with latest CCSM4 model runs (Lawrence et al., 2011).

$* * *$ Modeling results by Wisser et al. (2011) suggest permafrost thaw in peatlands about a factor of 2 slower than in mineral soils.

$* * * *$ Inferred from a LPJ $4 \times \mathrm{CO}_{2}$ simulation.

strong degradation of the surface layers of permafrost soils may occur under such pronounced Arctic warming (Saito et al., 2007; Yi et al., 2007; Lawrence and Slater, 2008; Zhang et al., 2008; Schaefer et al., 2011; Koven et al., 2011; Lawrence et al., 2011; Wisser et al., 2011).

Our modeling approach is meant to describe gradual permafrost degradation resulting from progressive active layer thickening, but it does not explicitly account for permafrost degradation by talik formation, erosion or thermokarst development - processes also of importance to the fate of future permafrost.

We assume a range of 1.4 to 2.0 for polar amplification, i.e. the average increase of annual average surface air temperatures in the permafrost region relative to the globalmean increase. We base this on an analysis of CMIP3 model (Meehl et al., 2005) projections, that derives a central 


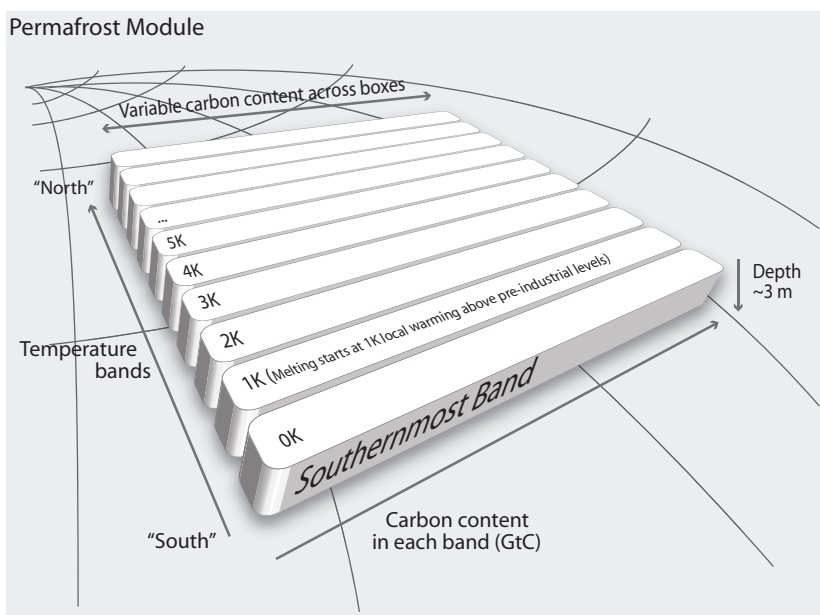

Fig. 1. Schematic overview of the simplified permafrost module with $n$ zonal bands (default $n=50$ ) in which thawing starts at different global warming levels. The carbon content of the represented permafrost fractions (approximating upper $3 \mathrm{~m}$ soil layer) can vary across the different zonal bands of equally spaced temperature intervals (default $=0.2 \mathrm{~K}$ spacing), with the default being an initially uniform carbon content distribution. Each zonal band is further subdivided into four soil pools with differing thaw and decomposition characteristics: mineral and peatland soils, divided into aerobic and anaerobic fractions.

estimate of $\sim 1.6$ with a $2-\sigma$ uncertainty of 0.2 (Frieler et al., 2011). Our upper end of the assumed uniform distribution considered here is slightly above the maximum value from AOGCMs (Atmosphere Ocean General Circulation Models) to account for cases of strong future sea ice retreat, which may only partly be captured by the analyzed CMIP3 AOGCMs (Stroeve et al., 2007). Such a strong retreat will increase polar temperature amplification in permafrost regions (Screen and Simmonds, 2010; Lawrence et al., 2008b). For the purpose of retrieving this polar amplification factor from the AOGCMs, the diagnosed permafrost region is here assumed as North-Eastern Europe (NEE), North-Asia/Siberia (NAS) and Alaska (ALA) following the region definitions of Giorgi and $\mathrm{Bi}(2005)$.

The two main soil types in permafrost regions - mineral and peatland soils - exhibit rather different properties of relevance to induced emissions (e.g. in terms of thermal soil conductivities or in terms of the ratio of aerobic vs. anaerobic soil conditions). By peatland soils we here understand soils with a high fraction of organic material (peat, litter). We thus subdivide the carbon in each zonal band into four pools: permafrost carbon stored in mineral and in peatland soils, each pool being subdivided into an aerobic and an anaerobic fraction. The largest carbon pool is characterized by physical properties of mineral soils and we assume that these soils contain $70-90 \%$ of the total permafrost carbon content (see $R_{\mathrm{ms}}$ in Table 1), given that an estimated $80 \%$ of carbon is stored in the upper $3 \mathrm{~m}$ frozen mineral soils (Tarnocai et al., 2009).
A key uncertainty is the fraction of carbon that might be decomposed under anaerobic conditions - resulting potentially in methane emissions to the atmosphere. Given the high warming potential of methane, the overall magnitude of the permafrost-carbon feedback will depend strongly on this fraction.

Based on Frolking et al. (2001) we assume an anaerobic fraction of $70 \%$ to $90 \%$ for peatland soils. We further assume slightly lower decomposition rates in peatland compared to mineral soils (ratios of 0.3 to 0.7 ) given that moss litter (which is abundant in peat soils) decomposes rather slowly (Hobbie et al., 2000; Scanlon and Moore, 2000). Mineral soils are dominated by aerobic conditions with only a small fraction of carbon in anaerobic environments $(90 \%-$ $99 \%$ aerobic fraction assumed). Although there is large uncertainty, Arctic climate change could increase water-logged areas (and hence the anaerobic part of decomposition) due to increased precipitation and associated soil moisture increases as well as thermokarst lake and wetland formation as icerich permafrost soils thaw and subside. On the other hand, increased drainage could lead to the opposite effect, even under increased precipitation. In this study, we hence keep the anaerobic area fractions constant.

In the anaerobic areas, not all decomposed carbon will be emitted as methane. Only half of the decomposed carbon in the anaerobic pool is converted to methane, following the process of methagonesis (Khvorostyanov et al., 2008a). Furthermore, on its pathway through the soil layers to the atmosphere, a part of this methane is oxidized. In mineral soils a large fraction of methane will likely be released via the fast pathways of ebullition and plant-mediated transport (in thermokarst lake regions), therefore bypassing the oxic layer (Wagner et al., 2009). We assume accordingly low oxidization rates of $10 \%-40 \%$ (see $\chi$ in Table 1). Given the dominance of slow diffusive methane transport in peatland soils, we assume much larger methane consumption in this pool, with average oxidation rates of $50 \%$ to $70 \%$. This range is based on observations of rather high oxidation in peat-moss ecosystems (Kip et al., 2011). Note however that the oxidization assumptions are subject to substantial uncertainty (Riley et al., 2011). For example, Walter and Heimann (2000) point to the large uncertainty in plant-mediated transport, assuming a best-estimate of $50 \%$ oxidation of methane.

While we do not explicitly account for the timescale of $\mathrm{CH}_{4}$ transport, we implicitly account for uncertainty in the timescale of $\mathrm{CH}_{4}$ release to the atmosphere by considering a large spread in assumed anaerobic decomposition times (see below). Furthermore, by assuming that a fixed fraction of methane is oxidized on its way to the atmosphere, we neglect the direct temperature sensitivity of oxidation rates.

The soil thawing (and re-freezing) rates are assumed to be half as fast in peatland soil areas compared to those of mineral soils because of high thermal insulation of the peat organic matter and high ice content. We tuned aerobic decomposition rates of the largest permafrost carbon stock, 
i.e. carbon in mineral soils in the intermediate pool, to cover overall turnover times of about 20 to $200 \mathrm{yrs}$. We do not simulate very slow decomposition of low quality carbon which decomposes on a millennial timescale. Thus, we neglect the part of the carbon soil pool which is very resistant to decomposition. The decomposition rate for aerobic conditions is much higher than for anaerobic conditions with modeling studies suggesting ratios of 10:1 to 40:1 (Frolking et al., 2001). Incubation experiments tend to favor slightly smaller ratios (Scanlon and Moore, 2000). Hence we assume a uniform range of 7:1 to 40:1. Both, oxic and anoxic decomposition rates in both soil types are adjusted depending on the soil temperatures. Our sampled parameter range corresponds to $Q_{10}$ values between 2 and 4 for the aerobic and between 2 and 6 for the anaerobic decomposition, accounting for the large uncertainty in temperature sensitivity of soil carbon mobilization (Davidson and Janssens, 2006). The large anaerobic $Q_{10}$ range expresses the larger uncertainty in temperature sensitivity of anaerobic decomposition (Walter and Heimann, 2000).

Additionally, we assume that oxic decomposition rates are dependent on soil moisture and implemented a simple soil moisture parameterization based on the annual cycle of soil temperature. The close link between soil temperature and soil moisture in our model is motivated by the fact that state-of-the-art climate models consistently show an increase in water availability (i.e. an increase in precipitation minus evaporation) in permafrost regions in a warmer climate (see figure 3.5 in Meehl, 2007).

\section{Results}

\subsection{Illustrative run with default parameter settings}

To illustrate the dynamics of our simplified modeling framework, we first show results for a single illustrative experiment for the high RCP8.5 scenario and with default parameters (see Table 1). In our model, permafrost starts degrading at the same level of warming in mineral and peatland soils, though it takes slightly longer for the heat anomaly to penetrate into the peatland soil (Fig. 2a, d). By 2050, only the southern latitudinal bands are subject to degradation, while by 2100 about half of the surface permafrost pool is thawed. Degradation of the northernmost permafrost areas only starts in the second half of the 22nd century.

Given the slow timescale of decomposition, permafrost carbon is released only gradually after thawing the surface soils and continues for centuries. The largest contribution to carbon emission comes from the aerobic decomposition of organic material located in the mineral soil pool (Fig. 2b). The peak emissions resulting from aerobic decomposition of peatland carbon is about an order of magnitude smaller compared to those from aerobic decomposition from mineral soils (see Fig. 2b, e). This is because of the assumed
20:80 ratio of total peatland to mineral soil carbon and the much higher anaerobic soil fraction in peatlands. Carbon release from the anaerobic pool describes the slowest timescale of permafrost dynamics due to the much lower decomposition rates in anaerobic compared to aerobic environments (a factor of ten difference for our default case). Carbon emissions due to aerobic decomposition fall pronouncedly after peaks in the early 22 nd century, indicating depletion of available soil carbon stocks over the multi-centennial timeframe considered here (see Fig. 2b, e). For the southern regions near-surface permafrost carbon gets depleted in the $23 \mathrm{rd}$ century.

Assuming that northern peatlands are complex, adaptive ecosystems (Belyea and Baird, 2006) this carbon pool might prove to be less vulnerable to loss due to self-sustaining vegetation and hydrology feedbacks (Frolking et al., 2011). We assume that the majority of this pool is subject to slow anaerobic decomposition, which is tantamount to assuming a larger resilience of peatland carbon to climate change.

We should add that we only quantify carbon fluxes from newly thawed permafrost soils (see Sect. 2.1). These fluxes will add to total soil carbon fluxes in the Arctic which are present regardless whether permafrost in the ground is thawed or still intact.

\subsection{Projections for RCPs including uncertainties}

In the following, we go beyond a consideration of our default parameter scenario and discuss model outcomes in the probabilistic framework in which we account for uncertainty in parameters of the carbon-cycle climate model and in the permafrost module (see Table 1).

For the mitigation scenario RCP3-PD that limits global mean temperature changes to below $2{ }^{\circ} \mathrm{C}$, cumulative $\mathrm{CO}_{2}$ emissions from newly thawed permafrost are $16 \mathrm{GtC}(68 \%$ uncertainty range: 9-30 GtC) by 2100 (Table 2). The analysis of RCP8.5, a scenario that implies extensive global warming reaching well above $10^{\circ} \mathrm{C}$ by 2150 (Fig. 3e), shows a pronounced degradation of near-surface permafrost by 2100 and almost complete thawing by 2200 . Modeling studies based on physical permafrost schemes consistently show pronounced permafrost degradation by 2100 , but to strongly differing extents (Saito et al., 2007; Lawrence et al., 2008a, 2011; Zhang et al., 2008; Yi et al., 2007; Euskirchen et al., 2006; Eliseev et al., 2009; Schaefer et al., 2011; Koven et al., 2011; Wisser et al., 2011). A direct comparison of permafrost degradation estimates is hindered given differences in forcing scenarios and in the definitions of permafrost degradation which are used in these studies (see e.g. discussion in Wisser et al., 2011). We tuned our default model parameters to simulated near-surface permafrost thaw in CCSM4 (Lawrence et al., 2011) which infers slightly slower degradation compared to previous model versions due to implementation of improved soil physics. For the RCP8.5 scenario, CCSM4 simulates an increase in thawed permafrost 

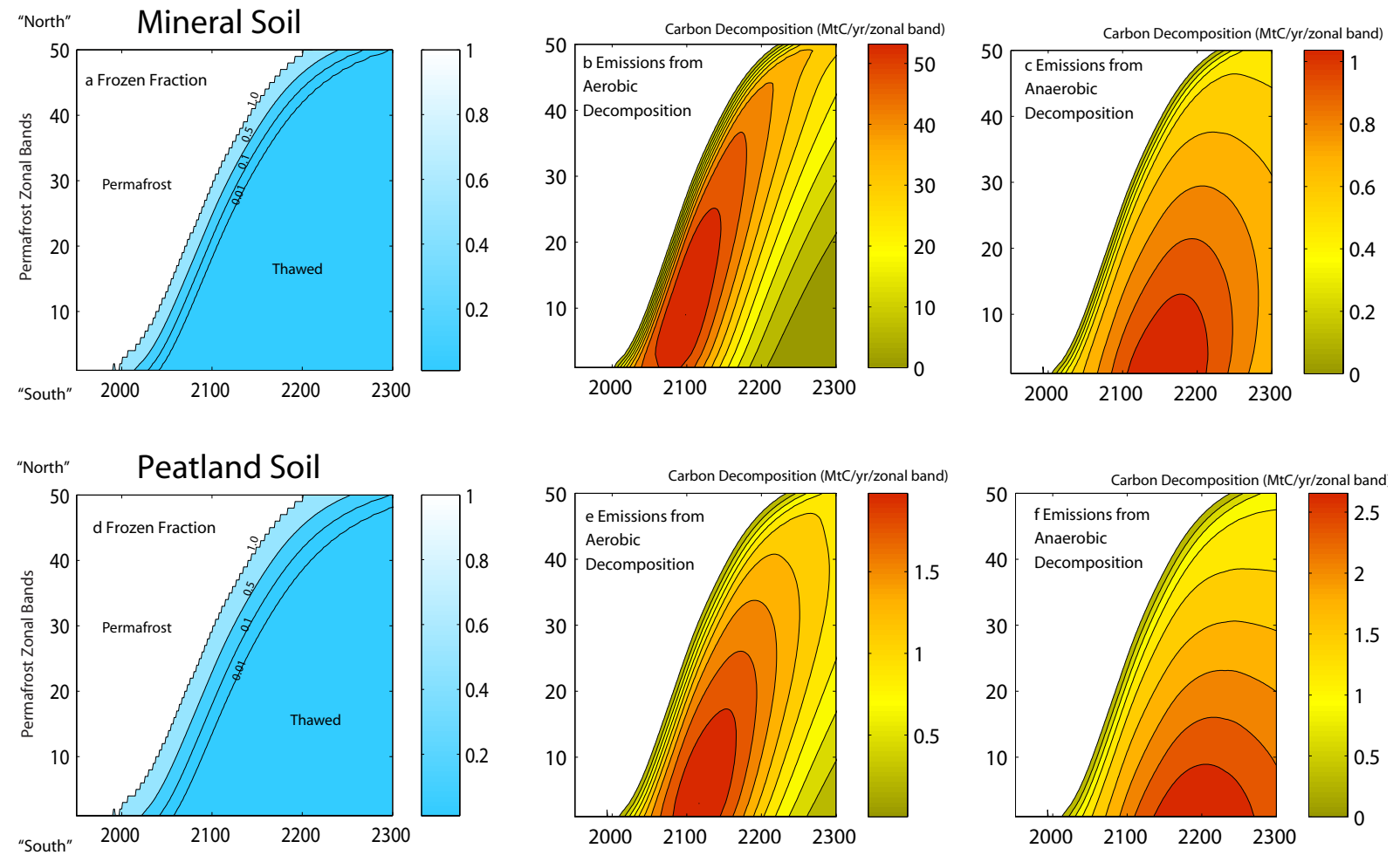

Fig. 2. Fraction of intact near-surface permafrost and carbon release in $\mathrm{MtC} \mathrm{yr}^{-1}$ per zonal band from mineral soil (upper row) and peatland soil (lower row) via aerobic (b, e) and anaerobic (c, f) decomposition, respectively, under the RCP8.5 scenario and illustrative default settings (see text and Table 2). Starting in the "Southernmos" zonal band, the thawing of the parameterized 3m thick soil layer progresses northward to colder zonal bands (vertical axis) over time (horizontal axis) (see a, d), being followed by carbon releases.

volume relative to present day by about $80 \%$ (45\% for the climate bias ameliorated run). This range is consistent with our simulated permafrost thaw of 41-81\% (68\% uncertainty range) by 2100 . Wisser et al. (2011) infer an increase of $20 \%$ for the thawed volume of northern American peat (with an average depth of $3.2 \mathrm{~m}$ ) by 2100 under the A1B scenario. Under the RCP6 scenario (which describes a forcing of similar strength) our median peat thaw is $18 \%$. While our estimates of permafrost degradation fall within the range of published studies, we do not cover the upper estimates of very rapid permafrost degradation as reported in Lawrence et al. (2008a) and Schaefer et al. (2011). Therefore we consider our results as conservative with respect to the timing and extent of permafrost degradation.

Given that microbial activity strongly increases for temperatures above the freezing point (Monson et al., 2006), large portions of soil carbon are subject to enhanced decomposition. Forcing our model with the high-emission scenario RCP8.5, thaw-induced $\mathrm{CO}_{2}$ emission rates increase over the 21 st century to about $2 \mathrm{GtC} \mathrm{yr}^{-1}$ in 2100 . This result is comparable to an extrapolated estimate based on net ecosystem carbon exchange measurements of permafrost patches, resulting in an emission estimate of $0.8-1.1 \mathrm{GtC} \mathrm{yr}^{-1}$ by 2100 (Schuur et al., 2009). This observationally inferred estimate is based on present-day permafrost thaw and gives a lower bound as future thaw will penetrate to larger depths and provide more carbon available for decomposition. The maximum of our projected emissions (median $2.5 \mathrm{GtC} \mathrm{yr}^{-1}$ ) is reached before the mid 22nd century (see Fig. 3c). The upper end of our $68 \%$ uncertainty range suggests $\mathrm{CO}_{2}$ emission up to $4 \mathrm{GtC} \mathrm{yr}^{-1}$. $\mathrm{CO}_{2}$ emissions resulting from the oxidation of thaw-induced methane and anaerobic $\mathrm{CO}_{2}$ production in the soils contribute to these large emission rates, but to a much smaller extent than the aerobic $\mathrm{CO}_{2}$ release (Fig. 3b, e). Cumulative $\mathrm{CO}_{2}$ emissions under RCP8.5 are $63 \mathrm{GtC}$ (33$114 \mathrm{GtC}$ ) by 2100 . By 2300 , about half of the permafrost carbon stock could be released to the atmosphere, with cumulative $\mathrm{CO}_{2}$ emissions being $380 \mathrm{GtC}(303-467 \mathrm{GtC})$ (Table 2).

Running a simple carbon-climate box model for the fossilintensive A2 scenario, (Raupach et al., 2008) estimate $\mathrm{CO}_{2}$ release from thawing permafrost soils until 2100. This study does not account for different temporal dynamics of aerobic/anaerobic and mineral/peatland soil pools and assumes a rather fast time constant for the $\mathrm{C}$ release from thawed permafrost carbon. Their estimate of $80 \mathrm{ppm}$ atmospheric $\mathrm{CO}_{2}$ concentration change from permafrost carbon is above our high-end estimate in 2100 (45 ppm for the 
Table 2. Median (68\%-range) estimates of permafrost characteristics under the four RCPs in year 2100, 2200 and 2300. The thawed permafrost area is provided, weighted in relation to the initial carbon pool distribution. Cumulative $\mathrm{emissions}$ of $\mathrm{CO}_{2}, \mathrm{CH}_{4}(\mathrm{without}$ contributions of carbon in the slow pool) and the share of carbon that is released as methane are shown for cumulative emissions from pre-industrial times until the indicated year. Subsequent rows indicate additional $\mathrm{CO}_{2}$ concentrations, $\mathrm{CO}_{2}$ radiative forcing, $\mathrm{CH}_{4}$ radiative forcing and global mean temperatures due to permafrost thawing above the background scenario. The permafrost carbon sensitivity LP indicates the change in the permafrost carbon stock until that year, given relative to that year's global mean surface temperature.

\begin{tabular}{|c|c|c|c|}
\hline RCP3-PD & 2100 & 2200 & 2300 \\
\hline Thawed Permafrost (\%) & $15(10-22)$ & $15(10-23)$ & $14(9-23)$ \\
\hline Cumulative $\mathrm{CO}_{2}$ Emissions (GtC) & $16(9-30)$ & $34(19-58)$ & $43(25-71)$ \\
\hline Cumulative $\mathrm{CH}_{4}$ Emissions $\left(\mathrm{MtCH}_{4}\right)$ & $131(49-321)$ & $353(134-852)$ & $535(207-1301)$ \\
\hline Carbon released as Methane $(\%)$ & $0.6(0.3-1.2)$ & $0.8(0.4-1.5)$ & $1(0.5-1.8)$ \\
\hline Added $\mathrm{CO}_{2}$ Concentration (ppm) & $4.5(2.3-8.4)$ & $7.5(3.8-13.6)$ & $8(4.1-14.7)$ \\
\hline Delta $\mathrm{CO}_{2}$ Radiative Forcing $\left(\mathrm{W} \mathrm{m}^{-2}\right)$ & $0.06(0.03-0.1)$ & $0.1(0.05-0.18)$ & $0.12(0.06-0.21)$ \\
\hline Delta $\mathrm{CH}_{4}$ Radiative Forcing $\left(\mathrm{W} \mathrm{m}^{-2}\right)$ & $0(0-0.01)$ & $0(0-0)$ & $0(0-0)$ \\
\hline Delta Temperature $\left({ }^{\circ} \mathrm{C}\right)$ & $0.03(0.01-0.06)$ & $0.06(0.03-0.13)$ & $0.08(0.04-0.16)$ \\
\hline Permafrost Carbon Sensitivity $\gamma_{\mathrm{LP}}\left(\mathrm{GtC}^{\circ} \mathrm{C}^{-1}\right)$ & $9.8(5.5-16.1)$ & $22.6(14-34.3)$ & $32.7(21.3-48)$ \\
\hline \multicolumn{4}{|l|}{ RCP45 } \\
\hline Thawed Permafrost (\%) & $26(18-37)$ & $35(23-51)$ & $38(26-58)$ \\
\hline Cumulative $\mathrm{CO}_{2}$ Emissions (GtC) & $27(14-048)$ & $74(42-0126)$ & $106(64-0178)$ \\
\hline Cumulative $\mathrm{CH}_{4}$ Emissions $\left(\mathrm{MtCH}_{4}\right)$ & $222(840-539)$ & $811(321-02012)$ & $1482(596-03725)$ \\
\hline Carbon released as Methane $(\%)$ & $0.6(0.3-1.2)$ & $0.9(0.4-1.6)$ & $1.1(0.5-2)$ \\
\hline Added $\mathrm{CO}_{2}$ Concentration (ppm) & $8.6(4.4-16)$ & $22(11.3-40.6)$ & $29.7(15.3-54.3)$ \\
\hline Delta $\mathrm{CO}_{2}$ Radiative Forcing $\left(\mathrm{W} \mathrm{m}^{-2}\right)$ & $0.08(0.04-0.15)$ & $0.2(0.11-0.36)$ & $0.27(0.15-0.46)$ \\
\hline Delta $\mathrm{CH}_{4}$ Radiative Forcing $\left(\mathrm{W} \mathrm{m}^{-2}\right)$ & $0(0-0.01)$ & $0.01(0-0.01)$ & $0(0-0.01)$ \\
\hline Delta Temperature $\left({ }^{\circ} \mathrm{C}\right)$ & $0.05(0.02-0.1)$ & $0.14(0.07-0.29)$ & $0.19(0.09-0.4)$ \\
\hline Permafrost Carbon Sensitivity $\gamma_{\mathrm{LP}}\left(\mathrm{GtC}^{\circ} \mathrm{C}^{-1}\right)$ & $10.2(5.9-16.6)$ & $24(15.6-35.3)$ & $32.3(22.2-45.1)$ \\
\hline \multicolumn{4}{|l|}{ RCP6 } \\
\hline Thawed Permafrost (\%) & $33(23-47)$ & $55(38-80)$ & $62(42-92)$ \\
\hline Cumulative $\mathrm{CO}_{2}$ Emissions (GtC) & $30(16-55)$ & $121(70-205)$ & $180(110-295)$ \\
\hline Cumulative $\mathrm{CH}_{4}$ Emissions $\left(\mathrm{MtCH}_{4}\right)$ & $247(93-601)$ & $1401(548-3499)$ & $2838(1117-7061)$ \\
\hline Carbon released as Methane $(\%)$ & $0.6(0.3-1.2)$ & $0.9(0.5-1.6)$ & $1.2(0.6-2.2)$ \\
\hline Added $\mathrm{CO}_{2}$ Concentration (ppm) & $10.5(5.4-19.5)$ & $42.3(22.3-78)$ & $59.8(33.1-108.7)$ \\
\hline Delta $\mathrm{CO}_{2}$ Radiative Forcing $\left(\mathrm{W} \mathrm{m}^{-2}\right)$ & $0.08(0.04-0.15)$ & $0.27(0.16-0.47)$ & $0.38(0.23-0.63)$ \\
\hline Delta $\mathrm{CH}_{4}$ Radiative Forcing $\left(\mathrm{W} \mathrm{m}^{-2}\right)$ & $0.01(0-0.02)$ & $0.01(0-0.03)$ & $0.01(0-0.03)$ \\
\hline Delta Temperature $\left({ }^{\circ} \mathrm{C}\right)$ & $0.05(0.02-0.11)$ & $0.2(0.1-0.46)$ & $0.3(0.15-0.65)$ \\
\hline Permafrost Carbon Sensitivity $\gamma_{\mathrm{LP}}\left(\mathrm{GtC}^{\circ} \mathrm{C}^{-1}\right)$ & $9.1(5.3-14.8)$ & $26.3(17.5-38.0)$ & $36.2(25.5-48.6)$ \\
\hline \multicolumn{4}{|l|}{ RCP85 } \\
\hline Thawed Permafrost (\%) & $57(41-81)$ & $100(91-100)$ & $100(100-100)$ \\
\hline Cumulative $\mathrm{CO}_{2}$ Emissions (GtC) & $63(33-114)$ & $302(199-405)$ & $380(303-467)$ \\
\hline Cumulative $\mathrm{CH}_{4}$ Emissions $\left(\mathrm{MtCH}_{4}\right)$ & $533(207-1336)$ & $5290(2002-12494)$ & $11666(4996-22719)$ \\
\hline Carbon released as Methane $(\%)$ & $0.7(0.3-1.2)$ & $1.4(0.7-2.5)$ & $2.3(1.1-3.9)$ \\
\hline Added $\mathrm{CO}_{2}$ Concentration (ppm) & $23.9(12.3-45.6)$ & $107.7(61.5-187.5)$ & $136.1(75.9-219)$ \\
\hline Delta $\mathrm{CO}_{2}$ Radiative Forcing $\left(\mathrm{W} \mathrm{m}^{-2}\right)$ & $0.13(0.07-0.23)$ & $0.3(0.19-0.46)$ & $0.35(0.22-0.49)$ \\
\hline Delta $\mathrm{CH}_{4}$ Radiative Forcing $\left(\mathrm{W} \mathrm{m}^{-2}\right)$ & $0.01(0-0.03)$ & $0.05(0.02-0.1)$ & $0.03(0.01-0.05)$ \\
\hline Delta Temperature $\left({ }^{\circ} \mathrm{C}\right)$ & $0.1(0.04-0.23)$ & $0.38(0.18-0.78)$ & $0.42(0.24-0.78)$ \\
\hline Permafrost Carbon Sensitivity $\gamma_{\mathrm{LP}}\left(\mathrm{GtC}^{\circ} \mathrm{C}^{-1}\right)$ & $11.9(7.1-19)$ & $28.6(21.2-37.4)$ & $34.7(25.5-44.3)$ \\
\hline
\end{tabular}


upper $68 \%$-range, RCP8.5, see Table 2). A recent study by Schaefer et al. (2011) infers a cumulative carbon flux of $190 \pm 64 \mathrm{GtC}$ from thawed permafrost by 2200 based on the A1B scenario. Our simulation results based on the RCP6 scenario (describing a forcing of comparable magnitude) suggest median emissions until 2200 of $121 \mathrm{GtC}$, with maximum emission of $205 \mathrm{GtC}$ for the $68 \%$ range. Key to the higher estimates of Schaefer et al. (2011) - despite being based on a smaller carbon pool - is their simulated fast permafrost degradation leading to $80-90 \%$ of permafrost carbon thaw before 2100 (while we infer an upper bound of $47 \%$ under RCP6). Contrary to their study, we account for slow decomposition of anaerobic pools and slower degradation and decomposition of peatland soils which explains why part of our considered permafrost carbon is more resistant to decay. In another recent study Koven et al. (2011) infer climate-induced cumulated $\mathrm{CO}_{2}$ fluxes from permafrost carbon of $37 \mathrm{GtC}$ until 2100 under the A2 scenario. Their simulated Arctic warming can be compared to model results from our RCP8.5 case where we infer integrated fluxes of 33-114 GtC. As Koven et al. (2011) do not simulate contributions from peatland carbon their estimate can be expected to fall on the low site of our range.

Lower carbon emissions are suggested by Zhuang et al. (2006) who applied a process-based emission model to infer an upper estimate of $17 \mathrm{GtC}$ resulting from permafrost thaw in the 21 st century for their high emission scenario (being slightly larger than RCP8.5).

Our inferred methane emissions from anaerobic decomposition of permafrost carbon are rather small, accounting for approximately $1 \%$ to $3 \%$ of the total carbon release. Due to the higher radiative forcing efficiency of methane, this relatively low fractional release of methane is important with respect to the total temperature increase, with up to a fifth of the thaw-induced forcing stemming from these methane releases under the high RCP8.5 scenario (cf. Table 2). Compared to current total anthropogenic methane emissions (roughly $300 \mathrm{MtCH}_{4} \mathrm{yr}^{-1}$ in year 2000), thawinduced methane emissions can reach a similar magnitude in the 22nd century (upper $68 \%$ range around $120 \mathrm{MtCH}_{4} \mathrm{yr}^{-1}$, see Fig. 3b), which corresponds to roughly a factor of 3 to 10 increase of 20th century natural net methane emissions from the Arctic (McGuire et al., 2009). An approximate doubling of global methane fluxes from wetlands by 2100 was inferred by Gedney et al. (2004).

If the Siberian Yedoma complex were to thaw as analyzed by one modeling study which factored in the heat release by microbial decomposition (Khvorostyanov et al., 2008a) - a process which we neglect in our considerations - permafrost $\mathrm{CH}_{4}$ release rates are likely to strongly increase. Future methane emission up to $30000 \mathrm{Tg} \mathrm{CH}_{4}$ is estimated from a complete thawing of the Yedoma carbon pool alone, based on up-scaling of observational estimates from extensive hotspot methane ebullition over thermokarst lakes (Walter et al., 2006, 2007b).
Our global-mean temperature simulations of the RCP scenarios, once including the permafrost module and once excluding it, indicate that the median warming by 2100 is not substantially altered. If we accounted for rather high rates of permafrost thaw as modeled by Lawrence et al. (2008a) and Schaefer et al. (2011) we expect to infer a non-negligible warming contribution by 2100 from permafrost carbon for the high anthropogenic emission scenarios. For the mitigation scenario RCP3-PD, our results suggest that permafrostcarbon feedbacks add negligibly to the warming. For the high RCP8.5 scenario, permafrost-carbon feedbacks can trigger additional global-mean temperature increase of about $0.1^{\circ} \mathrm{C}$ $\left(0.04-0.23^{\circ} \mathrm{C}\right)$ by 2100 , further increasing to $0.38^{\circ} \mathrm{C}(0.18-$ $0.78^{\circ} \mathrm{C}$ ) by 2200 and $0.42^{\circ} \mathrm{C}\left(0.24-0.78^{\circ} \mathrm{C}\right.$ ) in 2300 (see Table 2 and Fig. 3f). The intermediate RCP scenarios imply intermediate permafrost feedbacks, roughly proportional to their radiative forcing levels (see Table 2).

\subsection{Permafrost sensitivities}

The permafrost carbon pool is diminished by $11.9 \mathrm{GtC}$ (7.1$19 \mathrm{GtC})$ per degree of global warming in the 21 st century under RCP8.5. This is the RCP scenario that is most closely comparable to the SRES A2 scenario, for which the $\mathrm{C}^{4} \mathrm{MIP}$ intercomparison has been undertaken. Hence, the total carbon sensitivity of, on average, $79 \mathrm{GtC}^{\circ} \mathrm{C}^{-1}$ with a broad range from 20 to $177 \mathrm{GtC}^{\circ} \mathrm{C}^{-1}$ across the $\mathrm{C}^{4} \mathrm{MIP}$ models (Friedlingstein et al., 2006) could be slightly higher. When permafrost-carbon feedbacks are included, the average estimate would increase $15 \%$ (9\% to $24 \%$ ), shifting the best estimate of total land carbon sensitivity from $79 \mathrm{GtC}^{\circ} \mathrm{C}^{-1}$ by 2100 to above $90 \mathrm{GtC}^{\circ} \mathrm{C}^{-1}$.

Our results highlight the limitations of this indicator "carbon pool sensitivity", given that cumulative carbon releases per degree of warming are not a scenario- or timeindependent characteristic (Table 2). A common behavior can be described by an increase in carbon sensitivity with time which results from the slow time scale of permafrost carbon decomposition: carbon fluxes by 2300 are not only a consequence of permafrost thaw in the 23rd century but are also affected by emissions from soil which thawed earlier in the 21 st and 22nd century. As a consequence, carbon sensitivities are higher by a factor of three in 2300 compared to 2100 .

\section{Limitations}

The robustness of our results crucially depends on our assumptions made for parameterizing physical and microbial processes which determine the magnitude and timing of carbon release from permafrost soils. By having generously varied model parameters to account for known uncertainties we have spanned a broad possible range of future permafrost evolution. Yet our simplified representation of complex 

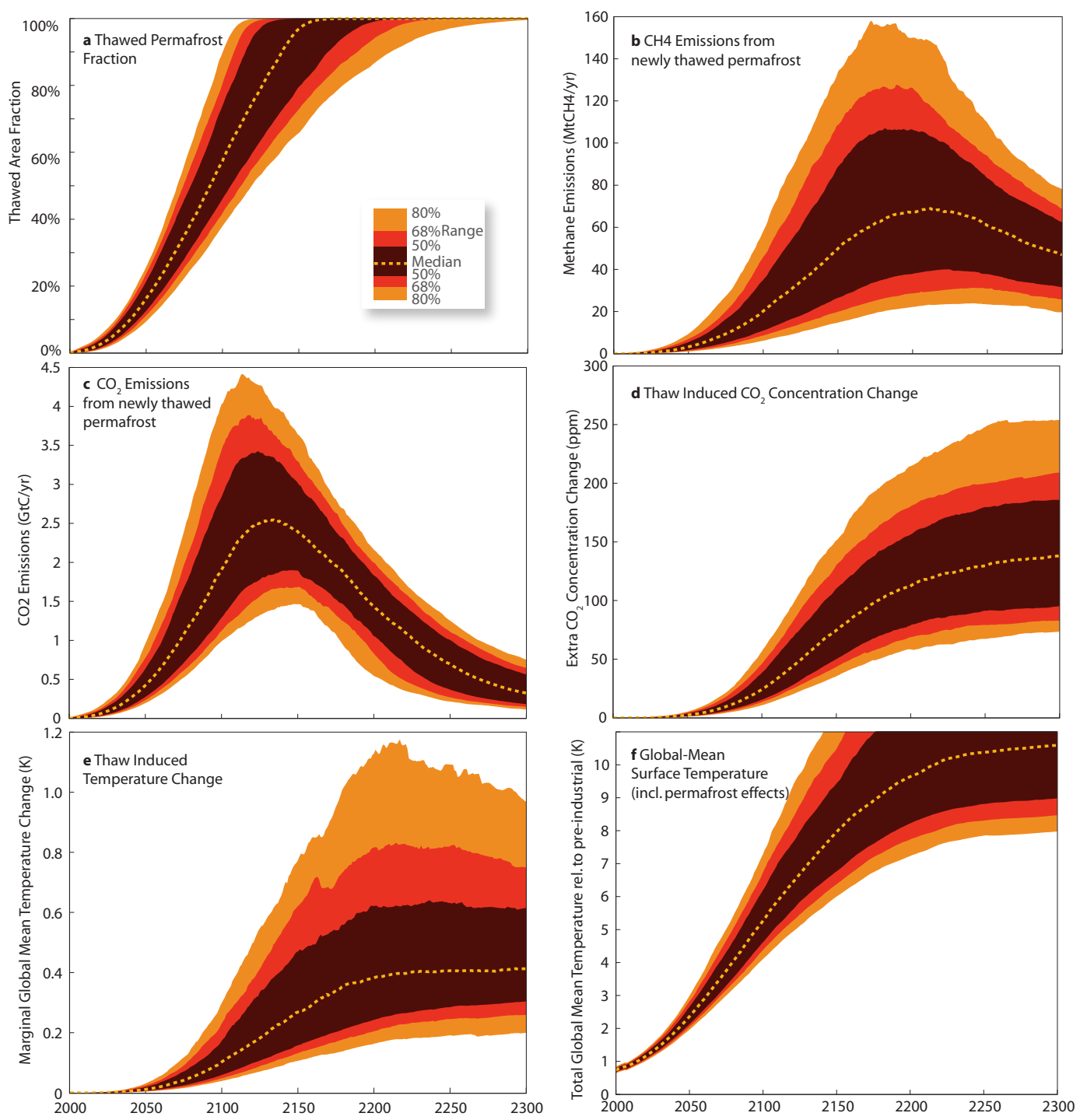

Fig. 3. This study's estimated ranges of thawed permafrost fraction (a), methane (b) and $\mathrm{CO}_{2}$ emissions (c) from carbon in newly thawed permafrost soils, thaw induced $\mathrm{CO}_{2}$ concentration (d) and temperature change (e), and the total anthropogenically induced global mean temperature anomaly (f). Results were obtained from an uncertainty analysis for the RCP8.5 scenario. The uncertainty ranges results from 2400 member ensemble simulations, using a Monte Carlo sampling that combines the joint distribution of 82 climate model parameters, 9 sets of 17 carbon cycle parameters and 22 independently sampled parameters of our permafrost model (see text and Table 1).

permafrost thawing dynamics and subsequent carbon release has several important limitations.

Effects of snow cover changes, which either can amplify or dampen soil warming, are not accounted for explicitly in our model. While snow state changes are likely to have strongly impacted recent soil temperatures trends, its role of affecting soil temperatures beyond 2050 is expected to exert a much smaller weight as surface air warming becomes the dominant driver for permafrost degradation (Lawrence and Slater, 2010).

Due to pronounced spatial inhomogenities in the soils and in local climatology, the "real world" change at specific permafrost sites will differ strongly from our simplified model which assumes that carbon is distributed homogeneously in each latitudinal band and is of the same quality (while carbon content is varied across latitudes). Highly sitespecific permafrost thaw can result from site-specific soil and vegetation cover properties, such as a strong insulation effect exerted by an organic-rich surface or a thin peat layer, or the effect on soil thermal properties resulting from unfrozen water in the ground (Alexeev et al., 2007; Yi et al., 2007; Nicolsky et al., 2007) and variability in excess ground ice concentration. Additionally, interaction of the $\mathrm{C}$ - and $\mathrm{N}$-cycle (Canadell et al., 2007) and various non-linear and complex 
ecosystem feedback loops (Heimann and Reichstein, 2008; Jorgenson et al., 2010) can play an important role in the fate of permafrost carbon but are not considered here.

We focus our analysis on the top $3 \mathrm{~m}$ of land permafrost soils where carbon densities are high and uncertainty about the rate of thaw of deep ground layers is not as important. For large warming anomalies on multi-centennial timescales, carbon release from deeper carbon reservoirs is likely. Of particular relevance is the potential degradation and emissions of highly labile carbon found in deeper layers of the Siberian Yedoma complex (Khvorostyanov et al., 2008b) and fluvial deposits (Tarnocai et al., 2009), with a potential to further increase emissions from permafrost. Furthermore, large amounts of carbon are likely to be stored in sub-sea permafrost (Shakhova et al., 2010a) and in methane hydrate deposits on continental margins (Archer et al., 2009). We did not account for these additional carbon sources and therefore our high-end estimate of $1000 \mathrm{GtC}$ of carbon being potentially vulnerable to future release is likely a conservative estimate. Furthermore, we only considered a fraction of $60 \%$ of soil carbon pool being eventually available for release. If we also considered carbon fluxes from the remainder carbon pool with decomposition on millennial timescales, our long term estimates by 2300 will be larger by about $10-20 \%$ (estimated from an additional ensemble with model parameters tuned to millennial decomposition).

A key question remains with respect to the impact of permafrost thaw on water table depth, which ultimately determines the fraction of carbon released as $\mathrm{CO}_{2}$ or as methane. This aspect is considered an obvious gap in stateof-the-art Earth system models (O'Connor et al., 2010). Thawing may lead to enhanced soil drainage (lowering of water table) while landscape collapse is likely to favor thermokarst lake or wetland formation, resulting in increased $\mathrm{CH}_{4} / \mathrm{CO}_{2}$ emission ratios. High rates of $\mathrm{CH}_{4}$ release from newly forming thermokarst lakes indicate that this process might be a crucial contributor to future methane emission from permafrost soils (Walter et al., 2007a). Apart from this effect on hydrology, soil thermal properties are changed with enhanced permafrost thaw, although this dynamic is not considered in our study.

With future permafrost thaw and Arctic temperature rise, vegetation cover will respond to more favorable growing conditions, resulting in expected higher $\mathrm{CO}_{2}$ sequestration in Arctic regions (Canadell et al., 2007; Friedlingstein et al., 2006). Nutrients, released during the decomposition of organic material, could support new forest and biomass buildup. We do not explicitly account for the effect of increased $\mathrm{CO}_{2}$ uptake by expansion of vegetation into thawed permafrost regions. From a radiative balance viewpoint, the carbon sequestration effect is likely to be compensated somewhat or in full by the lowering of albedo resulting from modified Arctic vegetation (Matthews and Keith, 2007). In case of very strong warming with a pronounced decrease in springtime snow-cover this compensation will be less effective (a decrease in albedo feedback) - while increased transpiration from enhanced forest cover and the associated positive water vapor feedback might become more important (Swann et al., 2010). Observed protection of permafrost through shrub expansion (Blok et al., 2010) was recently shown to be likely overcompensated by changes in surface albedo (Lawrence and Swenson, 2011).

Our results are limited by the realism of global-mean temperature projections: While our results cannot confidently project warmings of $10^{\circ} \mathrm{C}$, which is above the upper end of the AOGCM calibration range of MAGICC6 (approximately $6{ }^{\circ} \mathrm{C}$ ), our results can be taken as an indication of the timing and potential magnitude of permafrost feedback effects. The results that we present here, i.e. that permafrost-carbon feedbacks are relevant at the global scale and will become increasingly important on longer time horizons, are based on highly simplified representations of permafrost and carboncycle climate dynamics. Similar studies using process-based models that are constrained by observations are urgently needed to better quantify permafrost-carbon and other permafrost feedbacks more robustly.

\section{Conclusions}

The inclusion of a highly simplified, dynamic permafrost module into the reduced complexity carbon-cycle climate model MAGICC6 has shown how permafrost carbon emissions could affect long-term projections of future temperature change. Our results underline the importance of analyzing long-term consequences of land carbon emissions beyond 2100. Studies focusing on short time horizons (e.g. Anisimov, 2007) infer a rather small permafrost feedback, in line with our results, while climatic consequences of thawing permafrost soils become clearly apparent after 2100 for the medium and higher RCP scenarios. Even more pronounced than many other components of the Earth System, the permafrost feedback highlights the lagged and slow response to human perturbations. Once unlocked under strong warming, thawing and decomposition of permafrost can release amounts of carbon until 2300 comparable to the historical anthropogenic emissions up to 2000 (approximately $440 \mathrm{GtC}$, cf. Allen et al., 2009). Under the RCP8.5 scenarios - with cumulative $\mathrm{CO}_{2}$ emissions from newly thawed permafrost soils of $303 \mathrm{GtC}$ to $467 \mathrm{GtC}$ (up to $20 \%$ larger values when considering very slow decomposition of low quality carbon) this permafrost-carbon feedback could add nearly half a degree warming $\left(0.18-0.78^{\circ} \mathrm{C}\right)$ warming from 2200 onwards, albeit in a world that will already be dissimilar to the current one due to global-mean temperature levels near to and possibly in excess of $10^{\circ} \mathrm{C}$. Our method is however not able to bound a worst-case scenario. For example, if there is extensive thermokarst formation or subsea permafrost degradation (Shakhova et al., 2010a, b), substantial $\mathrm{CH}_{4}$ emissions could result from thawing these high Arctic ecosystems. 
For lower scenarios, e.g. the mitigation scenario RCP3$\mathrm{PD}$, our results suggest that future warming is unlikely to increase Arctic temperatures enough to release a large fraction of the carbon stored in permafrost soils, although up to $22 \%$ could be thawed already by 2100 . If strong mitigation of emissions is pursued, it seems still possible to prevent the release of large fractions of this permafrost carbon over the coming centuries.

\section{Appendix A}

\section{Model description}

The following Appendix describes our simplified permafrost module and its parameterizations.

\section{A1 Initial carbon pool distribution}

Our default carbon distribution assumes equal amounts of carbon in each of the zonal bands. These zonal bands represent carbon stores liable to thawing at different warming thresholds. In order to capture the uncertainty that a larger or smaller fraction of the total permafrost carbon might be subject to thawing for comparatively low temperature increases, we introduced flexibility in the model regarding this initial carbon distribution along the "North-South" axis. Depending on the input parameter $\varphi$, initial total carbon pool $C_{0}$ is distributed across our $n$ zonal bands $C_{i, 0}$ according to:

$C_{i, 0}= \begin{cases}\left(i \frac{|\varphi|}{n^{2}}+\frac{1-|\varphi|}{n}\right) \frac{1}{A_{\mathrm{tot}}} C_{0}, & -1 \leq \varphi<0 \\ \frac{1}{n} C_{0}, & \varphi=0 \\ \left((n-i+1) \frac{|\varphi|}{n^{2}}+\frac{1-|\varphi|}{n}\right) \frac{1}{A_{\mathrm{tot}}} C_{0}, & 0<\varphi \leq 1\end{cases}$

with $\mathrm{A}_{\text {tot }}$ being the normalization constant, ensuring that the individual contributions add up to $\mathrm{C}_{0}$ (surface area of the grey shaded region marked in Fig. A1), $\left(A_{\mathrm{tot}}=1-\frac{|\varphi|}{2}\left(1-\frac{1}{n}\right)\right)$. For the limit $\varphi=1$, the "northernmost" zonal band ( $\mathrm{i}=\mathrm{n})$ will only contain the small fraction $1 /\left(n^{2} \times A_{\text {tot }}\right)$ of the total carbon pool, while the southernmost zonal band $(i=1)$ will contain the largest fraction $1 /\left(n \times A_{\text {tot }}\right)$ with linear increasing carbon pool fractions in between. Graphically, the carbon pool fraction distributions that can be set via the $\varphi$ parameter can be represented by a horizontally striped trapeze, with the lower/upper parallel side approaching zero for $\varphi$ being set at 1 or -1 (see Fig. A1). This initial carbon pool in each zonal band is attributed to the mineral and peatland soil fractions using the parameters $R_{\mathrm{ms}}$, south for band $i=1$ and $R_{\mathrm{ms}}$, north for the "northernmost" band $i=n$, with linear interpolation for intermediate zonal bands.

\section{A2 The thawing threshold in each zonal band}

A regional warming threshold $\Delta T_{i}^{\text {thresh }}$ is attributed to each zonal band for describing the latitudinal dependency of per- mafrost thaw. A minimum warming for thaw is required in the southernmost band $\left(\Delta T_{\min }\right)$, and a maximum warming threshold in the northernmostGuten Mooooo band $\left(\Delta T_{\max }\right)$. Thus, by linearly interpolating between the zonal bands, the warming threshold in zonal band $\mathrm{i}$ is defined as:

$\Delta T_{i}^{\mathrm{thresh}}=\Delta T_{\min }+\frac{(i-1)\left(\Delta T_{\max }-\Delta T_{\min }\right)}{n-1}$

Using this threshold, we calculate the maximum thaw temperature reached during summer $\left(T_{i, t}^{\text {thaw }}\right)$ relative to the freezing point in each year $t$ in each zonal band:

$T_{i, t}^{\text {thaw }}=\alpha \Delta T_{\text {global }, t}-\Delta T_{i}^{\text {thresh }}$

with $\Delta T_{\mathrm{global}, t}$ being the global-mean, annual average temperature anomaly, $\alpha$ being the latitudinal amplification factor, i.e. the ratio at which permafrost regions are expected to warm relative to the global mean, assuming a linear relationship between regional and global warming (Santer et al., 1990; Mitchell, 2003; Frieler et al., 2011). As soon as global temperature increase is high enough to raise permafrost temperatures above zero in a given latitudinal band (i.e. $T_{i, t}^{\text {thaw }}>0$ ), permafrost thaw is initiated and soil carbon in this band becomes subject to decomposition.

We calculate the transformation from soil between the permafrost and non-permafrost area on an annual basis. The summer temperature in year $\mathrm{t}$ is simply multiplied with the effective thawing/refreezing rate $\beta_{x}$ to calculate the thawing or re-refreezing fractional depth $D_{t, t h a w}^{x}$ of each zonal band, with $D_{t}^{x}=\beta_{x} T_{i, t}^{\text {thaw }}$ ( $x$ denoting either "ms" or "peat" for the mineral or peatland soils). By choosing different settings for $\beta_{x}$, we account for the large uncertainty present in model simulations of permafrost thaw.

\section{A3 Decomposition rates and their sensitivities to soil moisture and temperature}

Oxic decomposition rates in peat and mineral soils are assumed to be dependent on two factors, i.e. soil moisture and soil temperature. In the following, we describe simple parametrizations of the soil moisture status and of the temperature dependency of decomposition to infer a formula for effective decomposition rates. For anoxic conditions, decomposition rates are a function of soil temperature only.

Using a simple sinusoidal function, we approximate the annual cycle of the effective soil temperature in each band $i$, to compute the monthly soil temperatures $T_{i, m}^{\text {soil }}$

$T_{i, m}^{\mathrm{soil}}=\frac{\Phi}{2} \sin \frac{\pi(m-1)}{11}-\frac{\Phi}{2}+T_{i, t}^{\mathrm{thaw}}(4)$,

with $m=1, \ldots, 12$ denoting the 12 months of year $t$, and $\Phi$ the amplitude of the mean soil temperature cycle in the upper 3 meters (estimated as $4-6{ }^{\circ} \mathrm{C}$ ) (cf. Khvorostyanov et al., 2008c). 
Building on the monthly soil temperatures in each latitudinal band, we linearly approximate the temperature dependency of soil moisture $W_{i, m}^{\text {soil }}$ according to model results from a $4 \times \mathrm{CO}_{2}$ run of the LPJ model (Sitch et al., 2003):

$W_{i, m}^{\text {soil }}=\left\{\begin{aligned} W_{\text {min }}, & m_{\mathrm{T}} T_{i, m}^{\text {soil }}+W_{\text {off }} \leq W_{\text {min }} \\ m_{\mathrm{T}} T_{i, m}^{\text {soil }}+W_{\text {off }}, & m_{\mathrm{T}} T_{i, m}^{\text {soil }}+W_{\text {off }}>W_{\text {min }}\end{aligned}\right.$

with $m_{T}$ determining the soil moisture temperature sensitivity (default of $0.03^{\circ-1}$ ). Following Wania et al. (2009), we describe the moisture modifier function $F(W)$ as:

$F\left(W_{i, m}^{\text {soil }}\right)=\frac{1-e^{-W_{i, m}^{\text {soil }}}}{1-e^{-1}}$

The temperature dependence of heterotrophic respiration is described by a modified Arrhenius equation (Lloyd and Taylor, 1994;

$F\left(T_{i, m}^{\text {soil }}\right)=e^{\lambda\left(\frac{1}{56.02}-\frac{1}{T_{i, m}^{\text {soil }}+46.02}\right)}$

with $\lambda$ describing the activation energy and $\mathrm{F}\left(T=20^{\circ} \mathrm{C}\right)$ often being called the " $Q_{10}$ " factor, representing the increase in the decomposition rate from $10^{\circ} \mathrm{C}$ to $20^{\circ} \mathrm{C}$.

Using results from Eqs. (6) and (7), the annual average decomposition rate $\theta_{t, i}^{\mathrm{ms}}$, aer for aerobic respiration in mineral soils is derived from the inverse turnover time $1 / \tau_{\mathrm{aer}}^{\mathrm{ms}}$ and modulated by the soil temperature modifier $F(T)$ and the moisture modifier $F(W)$. The time- and zonal band dependent decomposition rate $\theta_{t, i, \text { aer }}^{\mathrm{ms}}$ for the mineral soil type and aerobic decomposition segment is the annual average over monthly decomposition rates:

$\Theta_{\mathrm{t}, \mathrm{i}, \mathrm{aer}}^{\mathrm{ms}}=\frac{1}{\tau_{\mathrm{aer}}^{\mathrm{ms}}} F\left(T_{i, m}^{\mathrm{soil}}\right) F\left(W_{i, m}^{\mathrm{soil}}\right)$

The effective aerobic decomposition rates for peatland carbon pool fractions are assumed to be lower, proportional to $\theta_{t, i, a e r}^{\mathrm{ms}}$ using the proportionality factors $R_{\text {peat }} / \mathrm{ms}$ (assumed range 0.3 to 0.7$)$. Anaerobic decomposition is calculated by using Eq. (8) with a fixed soil moisture modifier $F\left(W_{i, m}^{\text {soil }}\right)=$ $1)$ and an aerobic to anaerobic proportionality factor $R_{\text {an/aer }}$ with a default value of 0.1 .

\section{A4 Area of aerobic and anaerobic decomposition}

The anaerobic area fraction $A_{t, i, a n}^{x}$ (for peatland or mineral soils) relates to the thawed permafrost area, so that the anaerobic area fraction $A_{t, i, a n}^{\prime x}$ in relation to the total zonal band

$A_{t, i, \text { an }}^{\prime x}=A_{\mathrm{an}}^{x}\left(1-A_{t, i, \mathrm{pf}}^{\prime x}\right)$

with $A_{t, i, p f}^{\prime x}$ being the fraction of intact permafrost, starting at 1.0 at the beginning of the simulations and then decreasing as warming progresses.

Unlike in a spatially resolved high resolution permafrost model coupled to an AOGCM, our simplified structure does

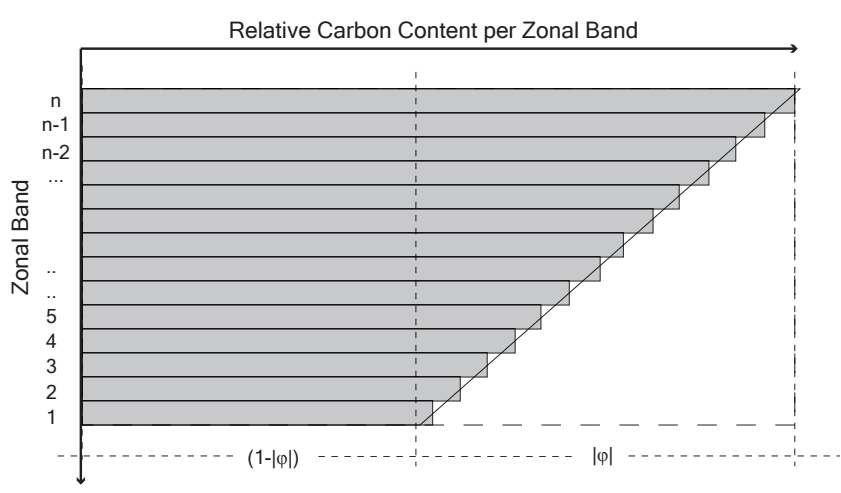

Fig. A1. Illustration of the simplified parameterisation to vary the north-south distribution of the initial carbon content $C_{0}$ across the n zonal bands with the parameter $\varphi$, here shown for a "northward" bias $(-1<\varphi<0)$. By default $(\varphi=0)$, each zonal band is allocated the same share, $1 / \mathrm{n} C_{0}$.

not permit to keep track of the carbon content of individual soil patches over time. Thus, for a change in the permanently frozen area fraction, an assumption is required of how much carbon is actually transferred between the respective carbon pools. We make a simplifying assumption of a uniformly distributed carbon density in each area type, anaerobic and aerobic, permafrost and non-permafrost. Ideally, a more highly resolved model would keep track of individual patches or parts of the permafrost column. Thus, the change of the thawed anaerobic ( $z=$ "an") or aerobic $(z=$ "aer") area $\Delta A_{t, i, z}^{\prime x}$ relative to the total zonal band area is given by the annual thawing rate $D_{t}^{x}$ and the respective permafrost area $A_{t, i, p f}^{\prime x}$

$\Delta A_{t, i, z}^{\prime x}=D_{t}^{x} A_{t, i, \mathrm{pf}}^{\prime x}$

In parallel to the fractional areas, the respective carbon pools $\mathrm{C}_{t, i, z}^{x}$ are updated, (i.e. the released carbon is subtracted from the pool) for both soil types $x$, i.e. peatland and mineral soil, each year $t$, zonal band $i$ and the anaerobic and aerobic decomposition segments $z$.

\section{A5 Calculating emissions}

The carbon release can now be calculated using the decomposition rates derived in Eq. (8) above and the calculated amount of thawed carbon being available in the four soil pools (mineral and peatland soil, under aerobic and anaerobic conditions). Given that pools in MAGICC are generally end of year $t /$ beginning of year $t+1$ quantities, and emissions the sum over year $t$, the carbon emissions from the aerobic and anaerobic carbon pools are derived as:

$E_{t, i, z}^{x}=\Theta_{t, i, z}^{x} \mathrm{C}_{t, i, z}^{x}$

Carbon emissions from aerobic decomposition occur in the form of carbon dioxide, and those from the anaerobic decomposition in the form of both methane and carbon dioxide. 
With half of the carbon in anaerobic areas being converted to $\mathrm{CH}_{4}$ in the soil, a certain fraction $\chi$ of the latter half is assumed to be oxidized on its way through the upper soil layers, before reaching the atmosphere.

\section{Supplementary material related to this article is available online at: http://www.biogeosciences.net/9/649/2012/ bg-9-649-2012-supplement.pdf.}

Acknowledgements. The authors wish to thank our colleagues whose input was crucial for building our simplified permafrost module. Our special thank is to Vladimir Romanovsky and Alexey Eliseev for discussing physics of permafrost soil thaw, to Charles Tarnocai for discussions about soil carbon characteristics, and to Sybill Schaphoff and Ursula Heyder for their input about dynamic carbon and vegetation modeling. Malte Meinshausen and Katja Frieler were supported by the Federal Environment Agency for Germany (UBA) under project UFOPLAN FKZ 370841103.

Edited by: J. Leifeld

\section{References}

Alexeev, V. A., Nicolsky, D. J., Romanovsky, V. E., and Lawrence, D. M.: An evaluation of deep soil configurations in the CLM3 for improved representation of permafrost, Geophys. Res. Lett., 34, L09502, doi:10.1029/2007GL029536, 2007.

Allen, M. R., Frame, D. J., Huntingford, C., Jones, C. D., Lowe, J. A., Meinshausen, M., and Meinshausen, N.: Warming caused by cumulative carbon emissions towards the trillionth tonne, Nature, 458, 1163-1166, 2009.

Anisimov, O. A.: Potential feedback of thawing permafrost to the global climate system through methane emission, Environ. Res. Lett., 2, 2-7, 2007.

Archer, D., Buffett, B., and Brovkin, V.: Ocean methane hydrates as a slow tipping point in the global carbon cycle, P. Natl. Acad. Sci. USA, 106, 20596-20601, 2009.

Belyea, L. R. and Baird, A. J.: Beyond "The limits to peat bog growth": cross-scale feedback in peatland development, Ecol. Monogr., 76, 299-322, 2006.

Berrittella, C. and van Huissteden, J.: Uncertainties in modelling $\mathrm{CH}_{4}$ emissions from northern wetlands in glacial climates: effect of hydrological model and $\mathrm{CH}_{4}$ model structure, Clim. Past, 5, 361-373, doi:10.5194/cp-5-361-2009, 2009.

Blok, D., Heijmans, M. M. P. D., Schaepman-Strub, G., Kononov, A. V., Maximov, T. C., and Berendse, F.: Shrub expansion may reduce summer permafrost thaw in Siberian tundra, Glob. Change Biol., 16, 1296-1305, 2010.

Canadell, J. G., Pataki, D. E., Pitelka, L. F., Canadell, J., Pataki, D., Gifford, R., Houghton, R., Luo, Y., Raupach, M., Smith, P., and Steffen, W.: Saturation of the Terrestrial Carbon Sink, in: Terrestrial Ecosystems in a Changing World, Global Change The IGBP Series, Springer Berlin Heidelberg, 59-78, 2007.
Cramer, W., Bondeau, A., Woodward, F. I., Prentice, I. C., Betts, R. A., Brovkin, V., Cox, P. M., Fisher, V., Foley, J. A., Friend, A. D., Kucharik, C., Lomas, M. R., Ramankutty, N., Sitch, S., Smith, B., White, A., and Young-Molling, C.: Global response of terrestrial ecosystem structure and function to $\mathrm{CO}_{2}$ and climate change: results from six dynamic global vegetation models, Global Change Biology, 7, 357-373, 2001.

Davidson, E. A. and Janssens, I. A.: Temperature sensitivity of soil carbon decomposition and feedbacks to climate change, Nature, 440, 165-173, 2006.

Dutta, K., Schuur, E. A. G., Neff, J. C., and Zimov, S. A.: Potential carbon release from permafrost soils of Northeastern Siberia, Glob. Change Biol., 12, 2336-2351, 2006.

Ehhalt, D., Prather, M. J., Dentener, F., Derwent, R. G., Dlugokencky, E., Holland, E., Isaksen, I. S. A., Katima, J., Kirchhoff, V., Matson, P., Midgley, P., and Wang, M.: Atmospheric Chemistry and Greenhouse Gases, in: Climate Change 2001: The Scientific Basis, Cambridge University Press, Cambridge, 2001.

Eliseev, A. V., Arzhanov, M. M., Demchenko, P. F., and Mokhov, I. I.: Changes in climatic characteristics of Northern Hemisphere extratropical land in the 21st century: Assessments with the IAP RAS climate model, IZV Atmos. Ocean. Phys., 45, 271-283, 2009.

Euskirchen, E. S., McGuire, A. D., Kicklighter, D. W., Zhuang, Q., Clein, J. S., Dargaville, R. J., Dye, D. G., Kimball, J. S., McDonald, K. C., Melillo, J. M., Romanovsky, V. E., and Smith, N. V.: Importance of recent shifts in soil thermal dynamics on growing season length, productivity, and carbon sequestration in terrestrial high-latitude ecosystems, Glob. Change Biol., 12, 731-750, 2006.

Friedlingstein, P., Cox, P., Betts, R., Bopp, L., Von Bloh, W., Brovkin, V., Cadule, P., Doney, S., Eby, M., Fung, I., Bala, G., John, J., Jones, C., Joos, F., Kato, T., Kawamiya, M., Knorr, W., Lindsay, K., Matthews, H. D., Raddatz, T., Rayner, P., Reick, C., Roeckner, E., Schnitzler, K. G., Schnur, R., Strassmann, K., Weaver, A. J., Yoshikawa, C., and Zeng, N.: Climate-carbon cycle feedback analysis: Results from the (CMIP)-M-4 model intercomparison, J. Climate, 19, 3337-3353, 2006.

Frieler, K., Meinshausen, M., Mengel, M., Braun, N., and Hare, W.: A scaling approach to probabilistic assessment of regional climate change, J. Climate, doi:10.1175/JCLI-D-11-00199.1, 2011.

Frolking, S., Roulet, N. T., Moore, T. R., Richard, P. J. H., Lavoie, M., and Muller, S. D.: Modeling northern peatland decomposition and peat accumulation, Ecosystems, 4, 479-498, 2001.

Frolking, S., Talbot, J., Jones, M. C., Treat, C. C., Kauffman, J. B., Tuittila, E.-S., and Roulet, N.: Peatlands in the Earth's 21st century climate system, Environ. Rev., 19, 371-396, 2011.

Gedney, N., Cox, P. M., and Huntingford, C.: Climate feedback from wetland methane emissions, Geophys. Res. Lett., 31, L20503, doi:10.1029/2004GL020919, 2004.

Giorgi, F. and Bi, X.: Updated regional precipitation and temperature changes for the 21 st century from ensembles of recent AOGCM simulations, Geophys. Res. Lett., 32, L21715, doi:10.1029/2005GL024288, 2005.

Grosse, G., Harden, J., Turetsky, M., McGuire, A. D., Camill, P., Tarnocai, C., Frolking, S., Schuur, E. A. G., Jorgenson, T., Marchenko, S., Romanovsky, V., Wickland, K. P., French, N., Waldrop, M., Bourgeau-Chavez, L., and Striegl, R. G.: Vulnerability of high-latitude soil organic carbon in 
North America to disturbance, J. Geophys. Res., 116, G00K06, doi:10.1029/2010JG001507, 2011.

Heimann, M. and Reichstein, M.: Terrestrial ecosystem carbon dynamics and climate feedbacks, Nature, 451, 289-292, 2008.

Hobbie, S. E., Schimel, J. P., Trumbore, S. E., and Randerson, J. R.: Controls over carbon storage and turnover in high-latitude soils, Glob. Change Biol., 6, 196-210, 2000.

Jorgenson, M. T., Romanovsky, V., Harden, J., Shur, Y., O’Donnell, J., Schuur, E. A. G., Kanevskiy, M., and Marchenko, S.: Resilience and vulnerability of permafrost to climate change, C. J. Forest Res., 40, 1219-1236, 2010.

Karhu, K., Fritze, H., HÄMÄLÄINEN, K., Vanhala, P., Jungner, H. g., Oinonen, M., Sonninen, E., Tuomi, M., Spetz, P., Kitunen, V., and Liski, J.: Temperature sensitivity of soil carbon fractions in boreal forest soil, Ecology, 91, 370-376, 2010.

Khvorostyanov, D. V., Ciais, P., Krinner, G., and Zimov, S. A.: Vulnerability of east Siberia's frozen carbon stores to future warming, Geophys. Res. Lett., 35, L10703, doi:10.1029/2008GL033639, 2008a.

Khvorostyanov, D. V., Ciais, P., Krinner, G., Zimov, S. A., Corradi, C., and Guggenberger, G.: Vulnerability of permafrost carbon to global warming, Part 2: sensitivity of permafrost carbon stock to global warming, Tellus B, 60, 265-275, 2008b.

Khvorostyanov, D. V., Krinner, G., Ciais, P., Heimann, M., and Zimov, S. A.: Vulnerability of permafrost carbon to global warming, Part 1: Model description and role of heat generated by organic matter decomposition, Tellus B, 60, 250-264, 2008c.

Kip, N., van Winden, J. F., Pan, Y., Bodrossy, L., Reichart, G.-J., Smolders, A. J. P., Jetten, M. S. M., Damste, J. S. S., and Op den Camp, H. J. M.: Global prevalence of methane oxidation by symbiotic bacteria in peat-moss ecosystems, Nature Geosci., 3, 617-621, 2011.

Koven, C. D., Ringeval, B., Friedlingstein, P., Ciais, P., Cadule, P., Khvorostyanov, D., Krinner, G., and Tarnocai, C.: Permafrost carbon-climate feedbacks accelerate global warming, P. Natl. Acad. Sci., 108, 14769-14774, 2011.

Lawrence, D. M. and Slater, A. G.: Incorporating organic soil into a global climate model, Clim. Dynam., 30, 145-160, 2008.

Lawrence, D. M., Slater, A. G., Romanovsky, V. E., and Nicolsky, D. J.: Sensitivity of a model projection of near-surface permafrost degradation to soil column depth and representation of soil organic matter, J. Geophys. Res.-Earth Surf., 113, F02011, doi:10.1029/2007JF000883, 2008a.

Lawrence, D. M., Slater, A. G., Tomas, R. A., Holland, M. M., and Deser, C.: Accelerated Arctic land warming and permafrost degradation during rapid sea ice loss, Geophys. Res. Lett., 35, L11506, doi:10.1029/2008GL033985, 2008b.

Lawrence, D. M. and Slater, A. G.: The contribution of snow condition trends to future ground climate, Clim. Dynam., 34, 969-981, 2010.

Lawrence, D. M., Slater, A. G., and Swenson, S. C.: Simulation of Present-day and Future Permafrost and Seasonally Frozen Ground Conditions in CCSM4, J. Climate, doi:http://dx.doi.org/10.1175/JCLI-D-11-00334.1, 2011.

Lawrence, D. M. and Swenson, S. C.: Permafrost response to increasing Arctic shrub abundance depends on relative influence of shrubs on local soil cooling versus large-scale climate warming, Environ. Res. Lett., 6, 045504, doi:10.1088/17489326/6/4/045504, 2011.
Lloyd, J. and Taylor, J. A.: On the Temperature-Dependence of Soil Respiration, Funct. Ecol., 8, 315-323, 1994.

Matthews, H. D. and Keith, D. W.: Carbon-cycle feedbacks increase the likelihood of a warmer future, Geophys. Res. Lett., 34, L09702, doi:10.1029/2006GL028685, 2007.

McGuire, A. D., Chapin, F. S., Walsh, J. E., and Wirth, C.: Integrated Regional Changes in Arctic Climate Feedbacks: Implications for the Global Climate System*, Annu. Rev. Environ. Res., 31, 61-91, 2006.

McGuire, A. D., Anderson, L. G., Christensen, T. R., Dallimore, S., Guo, L. D., Hayes, D. J., Heimann, M., Lorenson, T. D., Macdonald, R. W., and Roulet, N.: Sensitivity of the carbon cycle in the Arctic to climate change, Ecol. Monogr., 79, 523-555, 2009.

Meehl, G. A., Covey, C., McAvaney, B., Latif, M., and Stouffer, R. J.: Overview of the Coupled Model Intercomparison Project, B. Am. Meteorol. Soc., 86, 89-93, 2005.

Meehl, G. A., Stocker, T. F., Collins, W., Friedlingstein, P., Gaye, A., Gregory, J. M., Kitoh, A., Knutti, R., Murphy, J., Noda, A., Raper, S. C. B., Watterson, I., Weaver, A., and Zhao Chapter 10, Z.-C.: Global Climate Projections, IPCC Fourth Assessment Report, edited by: IPCC, Cambridge University Press, Cambridge, 2007.

Meinshausen, M., Raper, S. C. B., and Wigley, T. M. L.: Emulating coupled atmosphere-ocean and carbon cycle models with a simpler model, MAGICC6 -Part 1: Model description and calibration, Atmos. Chem. Phys., 11, 1417-1456, doi:10.5194/acp11-1417-2011, 2011.

Meinshausen, M., Smith, S., Calvin, K., Daniel, J., Kainuma, M., Lamarque, J. F., Matsumoto, K., Montzka, S., Raper, S., Riahi, K., Thomson, A., Velders, G., and van Vuuren, D. P.: The RCP greenhouse gas concentrations and their extensions from 1765 to 2300, Climatic Change, 19(1-2), 213-241, doi:10.1007/s10584011-0156-z., 2011b.

Mitchell, T. D.: Pattern scaling - An examination of the accuracy of the technique for describing future climates, Climatic Change, 60, 217-242, 2003.

Monson, R. K., Lipson, D. L., Burns, S. P., Turnipseed, A. A., Delany, A. C., Williams, M. W., and Schmidt, S. K.: Winter forest soil respiration controlled by climate and microbial community composition, Nature, 439, 711-714, 2006.

Moss, R. H., Edmonds, J. A., Hibbard, K. A., Manning, M. R., Rose, S. K., van Vuuren, D. P., Carter, T. R., Emori, S., Kainuma, M., Kram, T., Meehl, G. A., Mitchell, J. F. B., Nakicenovic, N., Riahi, K., Smith, S. J., Stouffer, R. J., Thomson, A. M., Weyant, J. P., and Wilbanks, T. J.: The next generation of scenarios for climate change research and assessment, Nature, 463, 747-756, 2010.

Nicolsky, D. J., Romanovsky, V. E., Alexeev, V. A., and Lawrence, D. M.: Improved modeling of permafrost dynamics in a GCM land-surface scheme, Geophys. Res. Lett., 34, L08501, doi:10.1029/2007GL029525, 2007.

O'Connor, F. M., Boucher, O., Gedney, N., Jones, C. D., Folberth, G. A., Coppell, R., Friedlingstein, P., Collins, W. J., Chappellaz, J., Ridley, J., and Johnson, C. E.: Possible role of wetlands, permafrost, and methane hydrates in the methane cycle under future climate change: A review, Rev. Geophys., 48, RG4005, doi:10.1029/2010RG000326, 2010.

Orr, J. C.: Global Ocean Storage of Anthropogenic Carbon (GOSAC), Final report, 128 pp., 2002. 
Raupach, M., Canadell, J., Dolman, J., Valentini, R., and Freibauer, A.: Observing a Vulnerable Carbon Cycle, in: The ContinentalScale Greenhouse Gas Balance of Europe, Springer New York, 5-32, 2008

Riley, W. J., Subin, Z. M., Lawrence, D. M., Swenson, S. C., Torn, M. S., Meng, L., Mahowald, N. M., and Hess, P.: Barriers to predicting changes in global terrestrial methane fluxes: analyses using CLM4Me, a methane biogeochemistry model integrated in CESM, Biogeosciences, 8, 1925-1953, doi:10.5194/bg-8-19252011, 2011.

Saito, K., Kimoto, M., Zhang, T., Takata, K., and Emori, S.: Evaluating a high-resolution climate model: Simulated hydrothermal regimes in frozen ground regions and their change under the global warming scenario, J. Geophys. Res., 112, F02S11, doi:10.1029/2006JF000577, 2007.

Santer, B. D., Wigley, T. M. L., Schlesinger, M. E., and Mitchell, J. F. B.: Developing Climate Scenarios from Equilibrium GCM Results, MPI, Hamburg, Germany, 47, 1990.

Scanlon, D. and Moore, T.: Carbon dioxide production from peatland soil profiles: The influence of temperature, oxic/anoxic conditions and substrate, Soil Sci., 165, 153-160, 2000.

Schaefer, K., Zhang, T., Bruhwiler, L., and Barrett, A. P.: Amount and timing of permafrost carbon release in response to climate warming, Tellus B, 63, 165-180, 2011.

Schewe, J., Levermann, A., and Meinshausen, M.: Climate change under a scenario near $1.5^{\circ} \mathrm{C}$ of global warming: monsoon intensification, ocean warming and steric sea level rise, Earth Syst. Dynam., 2, 25-35, doi:10.5194/esd-2-25-2011, 2011.

Schuur, E. A. G., Bockheim, J., Canadell, J. G., Euskirchen, E., Field, C. B., Goryachkin, S. V., Hagemann, S., Kuhry, P., Lafleur, P. M., Lee, H., Mazhitova, G., Nelson, F. E., Rinke, A., Romanovsky, V. E., Shiklomanov, N., Tarnocai, C., Venevsky, S., Vogel, J. G., and Zimov, S. A.: Vulnerability of permafrost carbon to climate change: Implications for the global carbon cycle, Bioscience, 58, 701-714, 2008.

Schuur, E. A. G., Vogel, J. G., Crummer, K. G., Lee, H., Sickman, J. O., and Osterkamp, T. E.: The effect of permafrost thaw on old carbon release and net carbon exchange from tundra, Nature, 459, 556-559, 2009.

Screen, J. A. and Simmonds, I.: The central role of diminishing sea ice in recent Arctic temperature amplification, Nature, 464, 1334-1337, 2010.

Shakhova, N., Semiletov, I., and Gustafsson, O.: Methane from the East Siberian Arctic Shelf Response, Science, 329, 1147-1148, 2010a.

Shakhova, N., Semiletov, I., Salyuk, A., Yusupov, V., Kosmach, D., and Gustafsson, O.: Extensive Methane Venting to the Atmosphere from Sediments of the East Siberian Arctic Shelf, Science, 327, 1246-1250, 2010b.

Sitch, S., Smith, B., Prentice, I. C., Arneth, A., Bondeau, A., Cramer, W., Kaplan, J. O., Levis, S., Lucht, W., Sykes, M. T., Thonicke, K., and Venevsky, S.: Evaluation of ecosystem dynamics, plant geography and terrestrial carbon cycling in the LPJ dynamic global vegetation model, Glob. Change Biol., 9, 161185,2003

Sitch, S., Huntingford, C., Gedney, N., Levy, P. E., Lomas, M., Piao, S. L., Betts, R., Ciais, P., Cox, P., Friedlingstein, P., Jones, C. D., Prentice, I. C., and Woodward, F. I.: Evaluation of the terrestrial carbon cycle, future plant geography and climate-carbon cycle feedbacks using five Dynamic Global Vegetation Models (DGVMs), Glob. Change Biol., 14, 2015-2039, 2008.

Smith, L. C., Sheng, Y., and MacDonald, G. M.: A first pan-Arctic assessment of the influence of glaciation, permafrost, topography and peatlands on Northern Hemisphere lake distribution, Permafrost Periglac., 18, 201-208, 2007.

Stroeve, J., Holland, M. M., Meier, W., Scambos, T., and Serreze, M.: Arctic sea ice decline: Faster than forecast, Geophys. Res. Lett., 34, L09501, doi:10.1029/2007GL029703, 2007.

Swann, A. L., Fung, I. Y., Levis, S., Bonan, G. B., and Doney, S. C.: Changes in Arctic vegetation amplify high-latitude warming through the greenhouse effect, P. Natl. Acad. Sci. USA, 107, 1295-1300, 2010.

Tarnocai, C., Canadell, J. G., Schuur, E. A. G., Kuhry, P., Mazhitova, G., and Zimov, S.: Soil organic carbon pools in the northern circumpolar permafrost region, Global Biogeochem. Cy., 23, GB2023, doi:10.1029/2008GB003327, 2009.

van Huissteden, J., Berrittella, C., Parmentier, F. J. W., Mi, Y., Maximov, T. C., and Dolman, A. J.: Methane emissions from permafrost thaw lakes limited by lake drainage, Nature Clim. Change, 1, 119-123, 2011.

van Vuuren, D., Edmonds, J., Kainuma, M., Riahi, K., Thomson, A., Hibbard, K., Hurtt, G., Kram, T., Krey, V., Lamarque, J.F., Masui, T., Meinshausen, M., Nakicenovic, N., Smith, S., and Rose, S.: The representative concentration pathways: an overview, Climatic Change, 109, 5-31, 2011.

Wagner, D., Liebner, S., and Margesin, R.: Global Warming and Carbon Dynamics in Permafrost Soils: Methane Production and Oxidation, in: Permafrost Soils, Springer Berlin Heidelberg, 219-236, 2009.

Walter, B. P. and Heimann, M.: A process-based, climate-sensitive model to derive methane emissions from natural wetlands: Application to five wetland sites, sensitivity to model parameters, and climate, Global Biogeochem. Cy., 14, 745-765, 2000.

Walter, K. M., Zimov, S. A., Chanton, J. P., Verbyla, D., and Chapin, F. S.: Methane bubbling from Siberian thaw lakes as a positive feedback to climate warming, Nature, 443, 71-75, 2006.

Walter, K. M., Edwards, M. E., Grosse, G., Zimov, S. A., and Chapin, F. S.: Thermokarst lakes as a source of atmospheric $\mathrm{CH} 4$ during the last deglaciation, Science, 318, 633-636, 2007a.

Walter, K. M., Smith, L. C., and Chapin, F. S.: Methane bubbling from northern lakes: present and future contributions to the global methane budget, Philos. T. R. Soc. A, 365, 1657-1676, 2007b.

Wania, R., Ross, I., and Prentice, I. C.: Integrating peatlands and permafrost into a dynamic global vegetation model - Part 2: Evaluation and sensitivity of vegetation and carbon cycle processes, Global Biogeochem. Cy., 23, GB3015, doi:10.1029/2008GB003413, 2009.

Wigley, T. M. L. and Raper, S. C. B.: Reasons for Larger Warming Projections in the IPCC Third Assessment Report, J. Climate, 15, 2945-2952, 2002.

Wisser, D., Marchenko, S., Talbot, J., Treat, C., and Frolking, S.: Soil temperature response to 21 st century global warming: the role of and some implications for peat carbon in thawing permafrost soils in North America, Earth Syst. Dynam., 2, 121-138, doi:10.5194/esd-2-121-2011, 2011.

Yi, S. H., Woo, M. K., and Arain, M. A.: Impacts of peat and vegetation on permafrost degradation under climate warming, Geo- 
phys. Res. Lett., 34, L16504, doi:10.1029/2007GL030550, 2007.

Zhang, Y., Chen, W. J., and Riseborough, D. W.: Transient projections of permafrost distribution in Canada during the 21st century under scenarios of climate change, Global Planet. Change, 60, 443-456, 2008.
Zhuang, Q. L., Melillo, J. M., Sarofim, M. C., Kicklighter, D. W., McGuire, A. D., Felzer, B. S., Sokolov, A., Prinn, R. G., Steudler, P. A., and $\mathrm{Hu}, \mathrm{S}$. M.: $\mathrm{CO}_{2}$ and $\mathrm{CH}_{4}$ exchanges between land ecosystems and the atmosphere in northern high latitudes over the 21st century, Geophys. Res. Lett., 33, L17403, doi:10.1029/2006GL026972, 2006. 